\title{
Nicel Analiz Problemlerinin Öğretiminde Akış Şemalarının Kullanılmasına Yönelik Öğretmen Adaylarının Görüşleri*
}

\section{Opinions of Teacher Candidates on the Use of Flowcharts in Teaching of Quantitative Analysis Problems}

\author{
Hatice KARAER
}

• Geliş Tarihi: 17.12.2018 • Kabul Tarihi: 06.12.2019• Çevrimiçi Yayın Tarihi: 24.02.2020

\section{$\ddot{\mathbf{O z}}$}

$\mathrm{Bu}$ araştırma, Analitik Kimya II dersindeki nicel analiz problemlerinin öğretiminde akış şemalarının kullanılabilir olduğunu göstermek ve kullanılmasına yönelik öğretmen adaylarının görüşlerini belirlemek amacıyla yapılmıştır. Araştırmanın katılımcılarını, ülkemizdeki bir devlet üniversitesinin eğitim fakültesinin kimya öğretmenliği programının ikinci sınıfında zorunlu ders olarak okutulan Analitik Kimya II dersine kayıtlı 13 ögrenci oluşturmaktadır. Araştırmanın verileri, derste çizilen akış şemalarından, şemalarının verilmesi sırasında tespit edilen nitel gözlemlerden, açık uçlu tek soru içeren görüş formundan ve yarı yapılandırılmış görüşmelerdeki soruların yanıtlarından toplanmıştır. Toplanan veriler içerik analiziyle okuyucunun anlayabileceği şekilde kategori ve temalar oluşturularak frekans ve yüzde oranları şeklinde sunulmuştur. Elde edilen bulgulara göre, problemlerinin öğretiminde akış şemalarının kullanılmasının oldukça iyi olduğu, problemlerin çözümünü kolaylaştırdığı, öğrencilerin hata yapma olasılığını azalttığı, doğru sonuca ulaşma becerisini kazandırdığı ve problem çözmeyi eğlenceli hale getirdiği vb. olumlu görüşler belirlenmiştir. Ayrıca öğretmen adayları öğretmen olduklarında öğrencilerine geleneksel yöntem yerine güncel öğretim yöntem ve teknikleri kullanarak derslerini işleyeceklerini belirtmişlerdir. Sonuç olarak nicel analiz problemlerinin öğretimini kolaylaştırmak, öğrencilere problem çözme becerisini kazandırmak, problem çözmeye karşı davranışlarının olumlu yönde gelişmesini sağlamak için akış şemalarının kullanılmasının yerinde olduğu söylenebilir. Geleceğin öğretmenlerinin öğrenci merkezli eğitimle derslerini işlemeleri için lisans eğitimlerinde böyle yöntem ve tekniklerle yetiştirilmesi önerilmektedir.

Anahtar sözcükler: nicel analiz, gravimetrik ve volumetrik analiz, akış şemaları, problem çözme yöntemi.

Atıf:

Karaer, H. (2020). Nicel analiz problemlerinin öğretiminde akış şemalarının kullanılmasına yönelik öğretmen adaylarının görüşleri. Pamukkale Üniversitesi Eğitim Fakültesi Dergisi, 50, 201225.doi:10.9779/pauefd.498647

\footnotetext{
* Bu çalışma uluslararası çağdaş eğitim araştırmaları kongresinde sunulan sözlü bildirinin yeniden düzenlenmesiyle hazırlanmıştır.

*** Dr. Öğr. Üyesi, Ondokuz Mayıs Üniversitesi, ORCID ID: 0000-0001-7745-9387, hkaraer@ omu.edu.tr
} 


\begin{abstract}
This study is conducted to demonstrate usability of flowcharts and to determine opinions of teacher candidates on the use of flowcharts in teaching of quantitative analysis problems in Analytical Chemistry II course. The study group consisted of 13 students enrolled in Analytical Chemistry II course, which was taught as a compulsory course in the second year of chemistry teaching program. The data were collected from the flowcharts drawn at lesson, from the qualitative observations identified during the drawing of the flowcharts of the problems in the course, from the feedback form and the answers to the questions in the semi structured interviews. According to the findings, the useful of flowcharts in teaching of the problems is a quite good, makes it easier to solve problems, reduces the probability of students making mistakes gives the ability to reach the right result and makes problem solving fun and so on positive opinions were determined. In addition, teacher candidates state that when they are teachers, they will teach their students at their lessons using contemporary teaching methods and techniques instead of traditional methods. As a result, it can be said that it is appropriate to use flowcharts to facilitate the teaching of quantitative analysis problem, to provide students with problem solving skills, and to ensure that their behaviour against problem solving develops positively. It is recommended that teacher candidates should be educated with such methods and techniques in their undergraduate training for future course of student-centred education.
\end{abstract}

Keywords: quantitative analysis problems, gravimetric and volumetric analysis, flowcharts, problem solving method

Cited:

Karaer, H. (2020). Opinions of teacher candidates on the use of flowcharts in teaching of quantitative analysis problems. Pamukkale Üniversitesi Eğitim Fakültesi Dergisi, 50, 201225.doi:10.9779/pauefd.498647 


\section{Giriş}

Problem, insanı huzursuz eden, birden fazla çözüm yolu olan ve kökeni insanın varoluşuna kadar uzanan bir durumdur. Genel olarak problem, gerçekte yaşanılan bir durumun şartlarıyla istenilen durumun şartlarının birbirinden farklı olmasında ortaya çıkar. Günlük hayatta problemlerle karşı karşıya kalan insanlar, huzura kavuşmak için çeşitli çözüm yolları araştırırlar, tamamı olmasa da bir kısmından nasıl kurtulacaklarına yönelik çözüm yollarını bulurlar, bulamadıklarında tekrar yeni çözüm yollarını araştııırlar (Aksoy, 2003; Doğanay, 2014; Gelbal, 1991; Güneş, 2014; Ünsal, 2010; Temel ve Morgil, 2013; Yıldızlar, 2013).

Problem her alanda olduğu gibi eğitim alanında da mevcuttur. Bugünkü öğretim programlarının temelini oluşturan güncel eğitim anlayışında; problem çözme öğrenilebilen bir beceri olarak kabul edilmektedir (MEB, 2018). Bu anlayışta öğrencilerden herhangi bir problemle karşı karşıya kaldıklarında çok yönlü araştırma yaparak çözümü kendilerinin bulmaları beklenirken, öğretmenlerden problemin çözümünü doğrudan vermek yerine öğrencilere rehberlik ederek çözüme ulaşacak yolları göstermeleri beklenmektedir. Ancak yapılan çalışmalarda öğretim programlarının amaç ve hedeflerine istenilen düzeyde ulaşmadığı, öğretmenlerin geleneksel yöntemle derslerini işledikleri ve öğrenci başarı düzeyinin düşük olduğu belirtilmektedir. Ayrıca bu durumu ortadan kaldırmak için öğretmenlerin güncel öğretim yöntem ve teknikleri kullanmaları ve öğrencilerine bilgiye ulaşma becerisini kazandırılmaları gerektiği vurgulanmaktadır (Danjuma, 2012; Gelbal, 1991; Hafsah, Rosnani, Zurida, Kamanuzaman \& Khoo, 2014; Karaer, 2006; Lorenzo, 2005; Okanlawon, 2010; Soylu ve Soylu, 2006). Örneğin ülkemizde yapılan merkezi sınavların (TEOG, LYS vb.) sık sık değiştirilme gerekçelerinden biri öğrencilerin akademik başarı düzeylerinin düşük olduğu ve en fazla fen bilimleri, fizik, kimya, biyoloji alanlarında görüldügü belirtilmektedir.

Problem deyince akla gelen ilk disiplin matematik ya da matematikle iç içe olan fen bilimleri gelse de hemen her alanda görüldüğünden problem çözme yöntemi tüm disiplinlerde kullanılmakta ve okul programlarının amaçlarında yer almaktadır (Altun ve Emir, 2008; Ayas, 1997; Ilgıın ve Arslan, 2012; Tekşan, 2013; Ünsal ve Moğol, 2008). Matematik, fen bilimleri derslerinin alt yapısını oluşturduğu için matematikteki eksik ya da yanlış öğrenilen herhangi bir bilgi diğer alanları da ister istemez etkilemektedir. Çalışkan, Sezgin-Selçuk ve Erol (2010), öğrencilerin fizik problemini çözme performansları ve strateji kullanmalarının öğretim sürecine pozitif yönde etkisinin olduğunu vurgulamışlardır. Ünsal'a, (2010) göre, problem çözme bir nevi buluş yoluyla öğretim yöntemi olup aşamalı bir süreci kapsamaktadır. Lorenzo’ya (2005) göre, problem çözme güçlü alan bilgisine, problem çözme stratejine ve özgüvene bağlıdır.

Problem çözme birbirini izleyen bir dizi aşamaları içeren süreç olduğundan öğrencilerin en fazla problemi tanıma ve fark etme aşamasında zorlandıkları belirtilmektedir (Türker-Biber ve Aylar, 2017; Eryılmaz-Toksoy ve Akdeniz, 2017). Problem çözme sürecinde öğrenciler problemi anlama, gerekli verileri toplama, ne istediğini fark etme, plan oluşturma, planın sonuca götürüp götürmeyeceğini kontrol etme vb. beceriler kazanmaktadır (Aydoğdu, 2000; Case \& Fraser, 1999; Cheng, She \& Huang. 2018; Doğanay, 2014; DeCaprio, 1981; Erdem, 2008; Gabel, Sherwood \& Enoch, 1984; Hicks \& Bevsek, 2012; Nakiboğlu ve Kalın, 2009; Novak \& Canas, 2006; 2007; She \& Huang, 2018; Ünsal ve Ergin, 2011; Van Domelen, 2006; Waddling, 1983; Wilder, 2014). Bu süreçte öğretmenler geleneksel yöntemle problemleri çözmek yerine öğrencinin dikkatini çekecek, probleme odaklayacak, derse aktif katılımlarını sağlayacak 
öğrenci merkezli güncel yöntem ve tekniklerden yararlanmaları (Sezgin-Selçuk, Çalışkan ve Erol, 2006; Uysal, 2010) ve onlara çözüm yollarını yaparak-yaşayarak yol göstermeleri gerekir ki anlamlı ve kalıcı öğrenme sağlanabilsin. Aksi takdirde öğrencilerin problemin çözümüne ulaşması mümkün olmayacak ya da çözümü gecikecektir.

Problem çözerken istenilen sonuca varabilmek için problemin türü ve karmaşıklığ önemlidir. Bazen öğrenciler mantık yürüterek çözüme ulaşılırken bazen mantığın yanında bilimsel yolları da kullanılmaları gerekebilir. Böyle bir durumla karşı karşıya kalan öğrencilerin problemle baş edebilmeleri için onlara araştırma, sorgulama, karar verme, eleştirel ve yansıtıcı düşünme vb. pek çok becerinin kazandırılmış olması beklenmektedir. Bunun için problemlerin çözümünü kolaylaştıran, öğrenmeyi eğlenceli hale getiren yöntem ve tekniklerden yararlanmak gerekir ki bunlardan birisi akış şemalarıdır (Çalışkan, Sezgin-Selçuk ve Erol, 2006; DeCaprio, 1981; Sezgin-Selçuk, Çalışkan ve Erol, 2007).

Akış şemalarının öğretimde kullanılması ve öğretmenler tarafından tercih edilmesinin nedeni; nesneler, olaylar ve eylemlerle ilgili organize edilmiş bilgi düzeyleri arasındaki ilişkiyi gösteren sistemleri içermesidir. Çoğunlukla ders kitaplarında tablo ve akış şeması şeklinde yer alan ve daha çok temel bir kavramı ifade eden görsel ya da sözel bilgileri içeren basit gösterimler olduğundan öğretim sürecini kısaltmakta ve öğrenmeyi kolaylaştırmaktadır (Kaya, 2006). Öğrenciler öğrendikleri yeni bilgilerle önceki bilgilerini birleştirerek zihinlerinde oluşturdukları şemalar yardımıyla ezberleme yapmadan karşılaştıkları problemlerin çözümüne ulaşabilirler. Nitekim problem çözerken akış şeması kullanıldığında öğrencilerin öğrenmesini kolaylaştırdığını belirten çalışmalar bulunmaktadır (Altun ve Arslan, 2006; Bamidele \& Oloyede, 2013; Copper \& Swaller, 1987; DeCaprio,1981; Erden,1986; Lorenzo, 2005; Van Domelen, 2006; Waddling, 1983; Yazgan, 2007). DeCaprio'ya (1981) göre, akış şemaları bir sürecin akışını veya prosedürünün resimli bir gösterimini temel alan yol haritası olduğundan işlem ya da prosedürün adımlarını tanımlama ve düzenlemede kullanılabilir.

Akış şeması, hiyerarşik, örümcek vb. kavram haritalama çeşitleri öğrencilerin anlamlı ve kalıcı öğrenmesinde etkili olurken başarılarını artırmaktadır (Bamidele \& Oloyede, 2013). Novak \& Canas (2006, 2007), kavram haritalamanın anlamlı öğrenmeyi kolaylaştırmada çok güçlü olduğunu, bir tür şablon olarak işlev gördügünü veya bilginin organize edilerek yapılandırılması için parça parça inşa edildiğini, basit bir araç bilgisiyle yeni bağlamlar kullanılmasına izin verdiğini ve kalıcı olduğunu belirtmişlerdir. Işıkdoğan ve Kargın (2010), zihinsel engelli öğrencilere okuduğunu anlama becerisini kazandırmak için kullandıkları hikâye haritasını şema formunda hazırlayarak öğrencilerin daha kolay hatırlamalarını ve akılda kalmasını sağlamışlardır. Bu amaçla hikâye bileşenlerini resimlerle göstermişler ve hikâyenin anlama becerisinde etkili olduğunu açıklamışlardır. Karabulut, Yıkmış, Özak ve Karabulut (2015), şemaya dayalı problem çözme stratejisi zihinsel yetersizliğe sahip öğrencinin problem çözme performansını artırdığını, artışın öğrenciye verilen öğretimden üç hafta sonra da devam ettiğini, öğretimin sonunda üç farklı problemi başlangıcına göre daha doğru çözebildiğini belirtmişlerdir. Erden (1986), ilkokula devam eden öğrencilerin dört işleme dayalı problemleri çözerken problemlerle ilgili uygun şema veya şekil kullandıklarını belirtmiştir. Önen, Saka, Erdem, Uzal ve Gürdal (2008), fen bilgisi öğretmenlerin kullandıkları öğretim tekniklerinde kavramları şema halinde göstermek amacıyla kavram haritasını kullandıklarını ve şema şeklinde kullanılmasının öğretimi kolaylaştırdığını belirtmişlerdir. Nakiboğlu, Şen Akgün ve Fidan 
(2016), Genel Kimya Laboratuvarı I deneylerinde akış şeması kullandıkları çalışmada öğretmen adaylarının başlangıçta akış şemasından haberdar olmadıklarını, çalışma sonunda akış şemasının ne olduğunun farkına vardıklarını, nasıl kullanıldığını öğrendiklerini, laboratuvarlarda akış şemalarına yer verildiğinde öğrenmenin kolaylaştığını ve zaman açısından tasarruf sağladığını açıklamışlardır. Waddling (1983), titrasyonla ilgili problemin hesaplamasında akış şemasının kullanılması öğrencinin özgüvenini arttırdığına ve becerilerini büyük ölçüde geliştirdiğine dikkat çekmiştir.

Literatür incelendiğinde değişik amaçlarla kullanılan akış şemalarını içeren çalışmalar az olduğu gibi bu araştırmada yer alan Analitik Kimya II dersindeki nicel analiz problemlerinin öğretiminde kullanıldığını gösteren ve kullanılmasına yönelik öğretmen adaylarının görüşlerini içeren herhangi bir çalışmaya rastlanmamıştır. Kimya problemlerini öğrencilere anlamlı öğretmek, kalıcı öğrenmeyi sağlamak ve kimyaya karşı tutumlarını olumlu yönde geliştirmek için öncelikle öğretmen adaylarının bu konuda yetiştirilmesi ve onların lisans eğitimlerinde kalıcı ve anlamlı öğrenme sağlayan değişik yöntem ve tekniklerin kullanılmasına önem verilmesi gerekmektedir.

$\mathrm{Bu}$ araştırma Analitik Kimya II dersindeki nicel analiz problemlerinin öğretiminde akış şemalarının kullanılabilir olduğunu göstermek ve kullanılmasına yönelik öğretmen adaylarının görüşlerini belirlemek amacıyla yapılmıştır. Bu nedenle bu araştırma nicel analiz problemlerinin öğretiminde akış şemalarının kullanılabilir olduğu göstermesi, akış şemalarının nasıl oluşturulduğuyla ilgili değişik örneklerin bulunması, problemlerin öğretiminde akış şemalarının kullanılmasına yönelik öğretmen adaylarının görüşlerini içermesi, geleceğin kimya öğretmenlerine öğrenci merkezli öğretimin nasıl uygulandığını göstermesi ve onları bu kültürle nasıl yetiştirmeleri gerektiğinin vurgulaması bakımından literatüre katk1 sağlayacağı düşünülmektedir. Ayrıca nicel analiz problemlerindeki işlem basamaklarını akış şemasıyla anlatan ilk çalışma olması nedeniyle Analitik Kimya II dersiyle ilişkili lisans programlarındaki (Kimya, kimya öğretmenliği, kimya mühendisliği, eczacılık vb.) öğrenci ve öğretim elemanlarına yararlı olacă̆ 1 söylenebilir.

Analitik Kimya II dersindeki nicel analiz problemlerinin öğretiminde akış şemalarının kullanılmasına yönelik öğretmen adaylarının görüş ve düşünceleri nelerdir? Sorusu araştırmanın problemi olarak alınmıştır.

Bu problem kapsamında iki alt problem belirlenmiş olup aşağıda verilmiştir:

1-Analitik Kimya II dersindeki nicel analiz problemlerinin öğretiminde akış şemaları kullanılabilir mi?

2-Akış şemalarının kullanılmasına yönelik öğretmen adaylarının görüş ve düşünceleri nelerdir?

\section{Yöntem}

$\mathrm{Bu}$ bölümde araştırmanın deseni, katılımcıları, akış şemalarının uygulanması, veri toplama araçları, verilerin analizi, geçerlilik ve güvenilirlik alt bölümleri yer almaktadır. 


\section{Araştırma Deseni}

$\mathrm{Bu}$ araştırmada "Nicel analiz problemlerinin öğretiminde akışşemalarının kullanılması" olgu olarak düşünüldüğünden nitel araştırma desenlerinden fenomenoloji (olgu-bilim) deseni kullanılmıştır. Çünkü Analitik Kimya II dersinde akış şemalarını içeren örnekler tahtaya çizildiğinde öğretmen adaylarında nasıl bir algı oluşturduğu, zihinlerinde akış şemalarını nasıl yapılandırdıkları, problemlerin öğretiminde akış şemalarının kullanılıp kullanılmayacaklarına yönelik görüş ve düşüncelerinin ne olduğunun ortaya çıkartılması amaçlandığından fenomenoloji deseni uygun görülmüş̧ür.

$\mathrm{Bu}$ desende araştırmacı olgunun kapsadığı ortak manaların ne olduğunu tespit etmek için öncelikle araştırmanın katılımcılarının deneyimlerini tanıması ve özünü nelerin oluştuğunu belirlemesi gerekir (Onat-Kocabıyık, 2016). Ayrıca araştırmacı, katılımcı görüşlerinden hareketle olgunun veya olayların yapısı ve süreci hakkında önemli bilgiler topladığı gibi katılımcıların olgu veya olaylarla ilgili yaşantılarının nasıl olduğu, algılarının neden oluştuğuyla ilgili görüş ve düşüncelerini belirlemelidir (Creswell, 2016; Johnson \& Christensen, 2014; Khan, 2014; Padilla-Diaz, 2015; Yüksel ve Yıldırım, 2015).

\section{Katılımcılar}

Araştırmada olgu bilim deseni kullanıldığından araştırmacıya ölçütü belirlemesine firsat veren, uygulanabilirliği kolay olan ve kısa zamanda sonuçlanan amaçlı örnekleme türlerinden ölçüt örnekleme kullanılmıştır. Patton (2015), amaçlı örneklemenin yaygın olarak kullanıldığını belirterek araştırmanın amacına uygun verileri toplamak için olgu ya da olaylarla ilgili bilgisi olan ve belirli özellikleri taşıyan katılımcılardan seçilmesi gerektiğini belirtmiştir. Amaçlı örneklemede katılımcı sayısı üç ile on arasında olabilir (Creswell, 2016; Gentles, Ploeg \& McKibben, 2015). Harsh'a (20011) göre, amaçlı örnekleme araştırmacının bilgi kaynaklarına ulaşmasını kolaylaştırmaktadır.

Araştırmanın katılımcıları seçilirken, kimya öğretmenliği programında okuyan, Analitik Kimya II dersini alan, nicel analiz problemlerin anlaşılmasında akış şemalarının kullanıldığından haberdar olan gönüllü öğretmen adayları vb. ölçütler aranmıştır. Bu ölçütleri sağlayan araştırmanın katılımcılarını ülkemizdeki bir devlet üniversitesinin kimya öğretmenliği programında Analitik Kimya II dersine kayıtlı 13 öğretmen adayı oluşturmaktadır. Katılımcıların 3'ü erkek 10’u kadın olup ikisi hariç diğerleri programa isteyerek gelmiş ve halen okumaktan memnundur.

\section{Akış Şemalarının Uygulanması}

Verilerin toplanmasında çeşitli veri kaynakları kullanılmış olup sırasıyla aşağıda verilmiştir:

1. Ders sorumlusu tarafından öğretmen adaylarına önerilen kaynaklardan "Analitik Kimya Temelleri” (Skoog, West \& Holler, 1996) adlı kitaptan alınan problemler ve tahtaya çizilen akış şemalarından,

2. Ders sırasında araştırmacı tarafindan yapılan ve daha sonra kayıt altına alınan nitel gözlemlerden,

3. Dönem sonunda tüm katılımcılara uygulanan görüş formundaki açık uçlu tek sorunun (Gravimetrik ve volumetrik analizlerle ilgili problemlerin tanınmasında kullanılan akıs şemalarına yönelik görüşlerinizi yazınız) yanıtlarından, 
4. Dönem sonunda gönüllü dört katılımcıyla yapılan yarı yapılandırılmış görüşmelerdeki soruların yanıtlarından toplanmıştır.

Yarı yapılandırılmış görüşme, araştırmacıya soracağı soruları içeren bir protokolü önceden hazırlama firsatı verebilir, görüşmenin gidişatına göre hazırladığı soruların dışında değişik soruları sorma esnekliği sağlayabilir, katılımcılardan yanıtlarını ayrıntılı şekilde açıklamalarını isteyebilir. Katılımcılar görüşme sırasında bir soruyu yanıtlarken başka sorularla birlikte yanıtlamışsa araştırmacı tekrar o soruyu sormayabilir (Ekiz, 2003). Yarı yapılandırılmış görüşmede sorulan sorular aşağıda verilmiştir:

1. Nicel analizlerle ilgili bir problemlerin çözümlerinden korkuyor musunuz?

2. Problemlerin tanınmasında akış şemalarının kullanılmasının herhangi bir etkisi oldu mu?

3. Problemler problem çözme yöntemine göre değil de klasik yönteme göre çözülmüş olsaydı problemleri anlama ve kavrama düzeyininiz nasıl olurdu?

4. Nicel analizlerle ilgili bir problemin akış şemasını oluşturabilir misiniz, bu konuda kendinize güveniyor musunuz?

5. Size nicel analizle ilgili herhangi bir problem verilmiş olsa akış şemasını çizebilir misiniz?

6. Nicel analizle ilgili herhangi bir problemin akış şeması verilmiş olsa probleme ait metni yazabilir misiniz?

7. Öğretmen olduğunuzda problemlerin anlaşılmasını kolaylaştırmak için akış şeması tekniğini kullanmayı düşünüyor musunuz?

\section{Verilerin Analizi}

Verilerin analizinde içerik analizi kullanılmıştır. İçerik analizi birbirine benzeyen ham veriler belirli kavram ve temalar çerçevesinde bir araya getirilerek okuyucunun anlayabileceği biçimde sunulmasıdır (Yıldırım ve Şimşek, 2006). Bu nedenle görüş formu ve yarı yapılandırılmış görüşmelerdeki soruların yanıtlarından oluşturulan kategori ve temalar frekans ve yüzde olarak tablolarda verilmiştir. Ayrıca yarı yapılandırılmış görüşmelerdeki sorulardan 5. Soru için öğretmen adaylarına verilen problem ve probleme ait gönüllü katılımcıların çizdiği akış şemalarından biri şekil 8'de; 6 . soru için verilen problem metni, akış şeması ve probleme ait katılımcılardan birinin yazdığı metin Şekil 9'da verilmiştir. Elde edilen tüm veriler için alanında uzman öğretim elemanlarının görüş ve önerileri alınmıştır.

\section{Geçerlilik ve Güvenilirlik}

Araştırmanın geçerlilik ve güvenilirliği iç ve dış şeklinde değerlendirmiştir. İç geçerlilik araştırmacının gözlemleri ile ilişki kurduğu olgu ya da olayların gerçeği yansıtması şeklinde tanımlanırken; dış geçerlilik araştırma sonuçlarının benzerlik gösteren ortam ve şartlara göre genelleştirilebilmesidir (Başkale, 2016; Yıldırım ve Şimşek, 2013). Bu araştırmada katılımcılara ait bilgiler katılımcılar bölümünde, verilerin toplanmasıyla ilgili bilgiler verilerin toplanmasında ayrıntılı şekilde açıklanması araştırmanın iç geçerliliğinin sağlandığı söylenebilir. Araştırmada veriler toplanırken neler yapıldığı, nelerle karşılaşıldığı ve analizin nasıl yapıldığına yönelik tüm bilgiler ilgili bölümlerde detaylandırılarak verildiğinden dış geçerliliğin sağlandığı söylenebilir. 
İç güvenilirlik başka araştırmacıların aynı verileri kullanarak aynı sonuçlara ulaşmasındaki tutarlılık şeklinde tanımlanırken dış güvenilirlik araştırmada ulaşılan sonuçların birbirine benzeyen ortam ya da şartlarda benzer sonuçlara ulaşmasıyla ilgili teyit edilmesidir (Başkale, 2016; Yıldırım ve Şimşek, 2013). Bu yüzden katılımcı görüşlerinden oluşturulan kategori ve temaların uygunluğu için uzman öğretim elemanlarının görüşlerinin alınması iç güvenilirliğinin sağlandığı söylenebilir. Elde edilen bulgularla araştırma sonuçlarının karşılaştırılması amacıyla uzman görüşüne başvurulması ve araştırmacının araştırmadaki rolünü açıkça göstermesi dış güvenliliğinin sağlandığı söylenebilir.

\section{Bulgular}

Bu bölüm alt problemlere ilişkin bulguları içerdiğinden iki alt başlık halinde verilmiştir.

\section{Birinci Alt Probleme İlişkin Bulgular}

Nicel analiz problemlerinin öğretiminde akış şemalarının kullanılabilir olduğunu gösteren örnekler Şekil 1-7'de verilmiş olup birbirleriyle benzerlikleri ve farklılıkları açıklanmıştır.

Bir ham petrol numunesinin 50,0 gramındaki
$\mathrm{H}_{2} \mathrm{~S}$, damıtma ile uzaklaştırıldiktan sonra bir
$\mathrm{CdCl}_{2}$ çözeltisinde tutuluyor. Oluşan CdS
çökeleği süzülüyor, y1kanıyor ve CdSO ${ }_{4}{ }^{\prime} \mathrm{e}$
dönüştürülüyor. $0,108 \mathrm{CdSO}_{4}$ elde edildiğine
göre numunedeki $\mathrm{H}_{2} \mathrm{~S}^{\prime}$ nin yüzdesini
hesaplayız.

Şekil 1. Gravimetrik analizle ilgili 1. problem ve problemin öğretiminde kullanılan akış şeması

Şekil 1 gravimetrik analizle ilgili tek bileşenli bir numunenin analizini içermektedir. Problemde 50 gram ham petrol numunesindeki hidrojen sülfür $\left(\mathrm{H}_{2} \mathrm{~S}\right)$ gazının ne kadar kadminyum klorür $\left(\mathrm{CdCl}_{2}\right)$ çözeltisinde tutulduğu ve ne kadar kadminyum sülfür $(\mathrm{CdS})$ oluştuğu verilmemiş, sadece ham petrol numunesinin ve tüm gravimetrik işlemler tamamlandıktan sonra oluşan kadminyum sülfatın $\left(\mathrm{CdSO}_{4}\right)$ kütleleri verilmiştir. Numunedeki aranan maddenin $\mathrm{H}_{2} \mathrm{~S}$, çöktürücü reaktifin $\mathrm{CdCl}_{2}$ tartılan maddenin $\mathrm{CdSO}_{4}$ ve deneysel işlem basamakları görselleştirilerek açıklandığı için problemin öğretimini kolaylaşmıştır. 
Klorür ve iyodür iyonları 0,6407 gramlık bir numuneden $0,4430 \mathrm{~g}$ gümüş̧ halojen çökeleği elde edilmektedir. AgI'v1 $\mathrm{AgCl}$ 'e dönüş̧ürmek için bu çőkelek $\mathrm{Cl}_{2}$ gazı akımında iyice 1sitıliyor ve sonuçta $0,3181 \mathrm{~g}$ çökelek elde ediliyor. Numunedeki klorür ve iyodür yüzdelerini hesaplayınız.

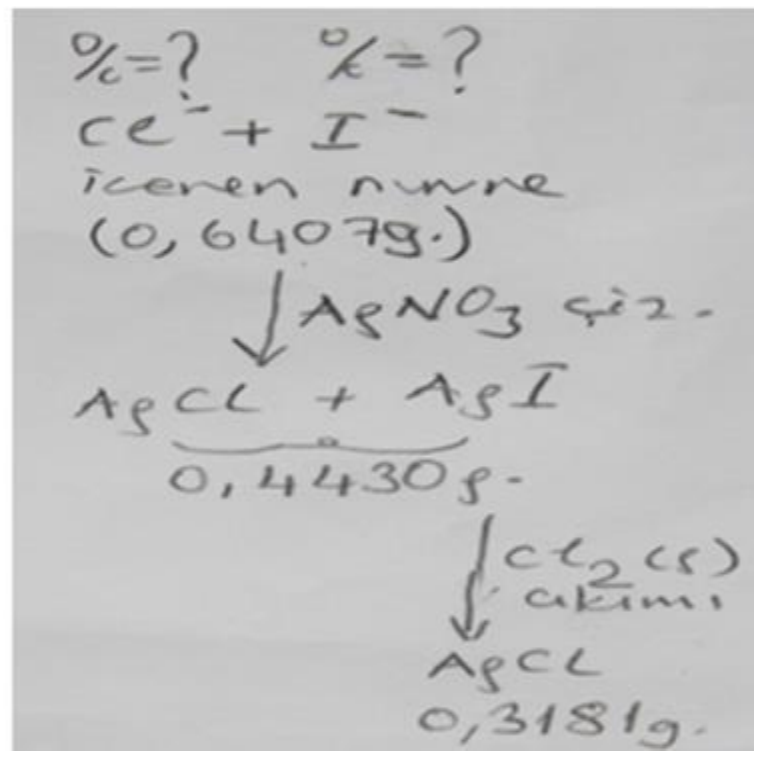

Şekil 2. Gravimetrik analizle ilgili 2. problem ve problemin öğretiminde kullanılan akış şeması

Şekil 2'deki problem, Şekil 1'deki gibi gravimetrik analizle ilgili olup tek bileşenli değil iki bileşenli bir numuneyi içermektedir. Şekil 1'de her adımda oluşan maddelere ait sayısal veri bulunmazken Şekil 2'de verilmiştir. Problemde aranan maddelerin numunedeki klorür $\left(\mathrm{Cl}^{-}\right)$ve iyodür $\left(\mathrm{I}^{-}\right)$iyonları, tartılan maddenin gümüş klorür $(\mathrm{AgCl})$, çöktürücü reaktif problem metninde verilmemiş olsa da tartılan maddelerden hareketle gümüş nitrat $\left(\mathrm{AgNO}_{3}\right)$ olduğu tahmin edilerek akışşemasında gösterildiğinden problemin öğretimini kolaylaştırılmıştır.

Magnezyum klorür ve sodyum klorür içeren bir numunenin 6,881 gramı, suda çözülerek hacmi $500 \mathrm{~mL}$ 'ye tamamlaniyor. Bu çözeltinin $50 \mathrm{~mL}$ 'sinin analizinde $0,5923 \mathrm{~g}$ gümüş klorür oluşuyor. Diğer bir $50 \mathrm{~mL}$ 'lik numunedeki magnezyum, $\mathrm{MgNH}_{4} \mathrm{PO}_{4}$ şeklinde çöktürülüyor ve isıtılarak $0,1796 \mathrm{~g} \mathrm{Mg}_{2} \mathrm{P}_{2} \mathrm{O}_{7}$ ye dönüştürülüyor. Numunedeki tuzların yüzdelerini hesaplayınız.

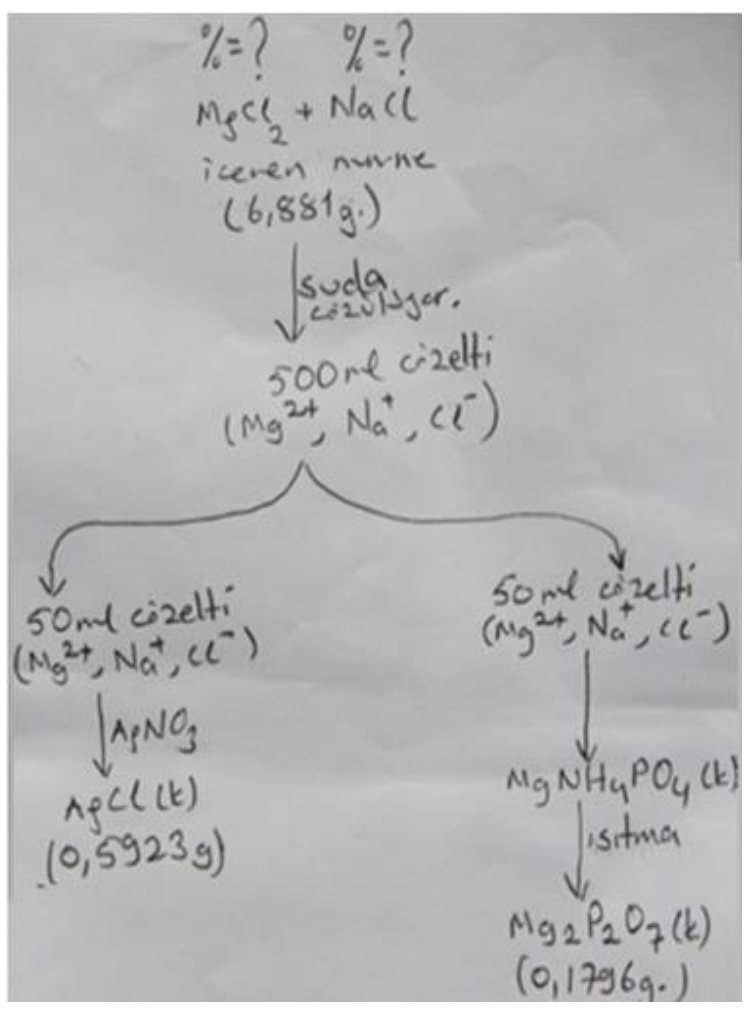

Şekil 3. Gravimetrik analizle ilgili 3. problem ve problemin öğretiminde kullanılan akış şeması 
Şekil 3'deki problem Şekil 1-2 gibi gravimetrik analizle ilgili olurken Şekil 2'deki gibi iki bileşenlidir. Ancak aynı anyona sahip iki farklı tuzu içeren bir numunenin iki kısımda analizini içermektedir. Analizin birinci kısmında numunedeki magnezyum klorür $\left(\mathrm{MgCl}_{2}\right)$ ve sodyum klorür $(\mathrm{NaCl})$ reaktif ilavesinden sonra gümüş klorürü $(\mathrm{AgCl})$ oluştururken, ikinci kısmında numunedeki $\mathrm{MgCl}_{2}$ 'ün bir dizi gravimetrik işlemlerden sonra magnezyum pirofosfat'1 $\left(\mathrm{Mg}_{2} \mathrm{P}_{2} \mathrm{O}_{7}\right)$ oluşturduğu akış şemasında gösterilmiştir. Bu haliyle Şekil 3, Şekil 1 ve 2'deki problemlerden farklıdır. Şekil 3'ün Şekil 2'deki problemden bir diğer fark1, numune bileşenlerinin çözelti ortamına alınması ve analiz için çözeltinin onda birinin kullanılmasıdır. Şekil 3'deki problemde aranan maddeler $\mathrm{MgCl}_{2}$ ve $\mathrm{NaCl}$, tartılan maddeler birinci kısımda $\mathrm{AgCl}$, ikinci kısımda $\mathrm{Mg}_{2} \mathrm{P}_{2} \mathrm{O}_{7}{ }^{\prime}$ tır. Şekil 2'deki gibi her iki kısımdaki çöktürücü reaktifler problemin asıl metninde verilmemiş olsa da tartılan maddelerden hareketle birinci kısımda $\mathrm{AgNO}_{3}$, ikinci kısımda amonyum hidrojen fosfat, $\left(\mathrm{NH}_{4}\right)_{2} \mathrm{HPO}_{4}$ olacağı tahmin edilerek akış şemasında gösterildiğinden problemin öğretimini kolaylaştırılmıştır.

\section{$4,258 \mathrm{~g}$ 'lik bitkisel bir gidadaki fosfat, $50,00 \mathrm{~mL}$} $0,0820 \mathrm{M} \mathrm{AgNO} 3$ ilavesiyle $\mathrm{Ag}_{3} \mathrm{PO}_{4}$ olarak çöktürülüyor.

$$
\mathrm{Ag}^{+}+\mathrm{HPO}_{4}{ }^{2-} \quad \mathrm{Ag}_{3} \mathrm{PO}_{4}(\mathrm{k})+\mathrm{H}^{+}
$$

Katı süzülüp yıkaniyor ve süzüntü ve yıkama suları tam olarak 250 ml'ye seyreltiliyor. Bu çözeltiden alınan 50 mL'lik bir Kisiminin titrasyonunda 4,64 $\mathrm{mL} 0,0625 \mathrm{M} \mathrm{KSCN}$ harcaniyor. Bu analizin sonucunu $\mathrm{P}_{2} \mathrm{O}_{5}$ yüzdesi olarak veriniz.

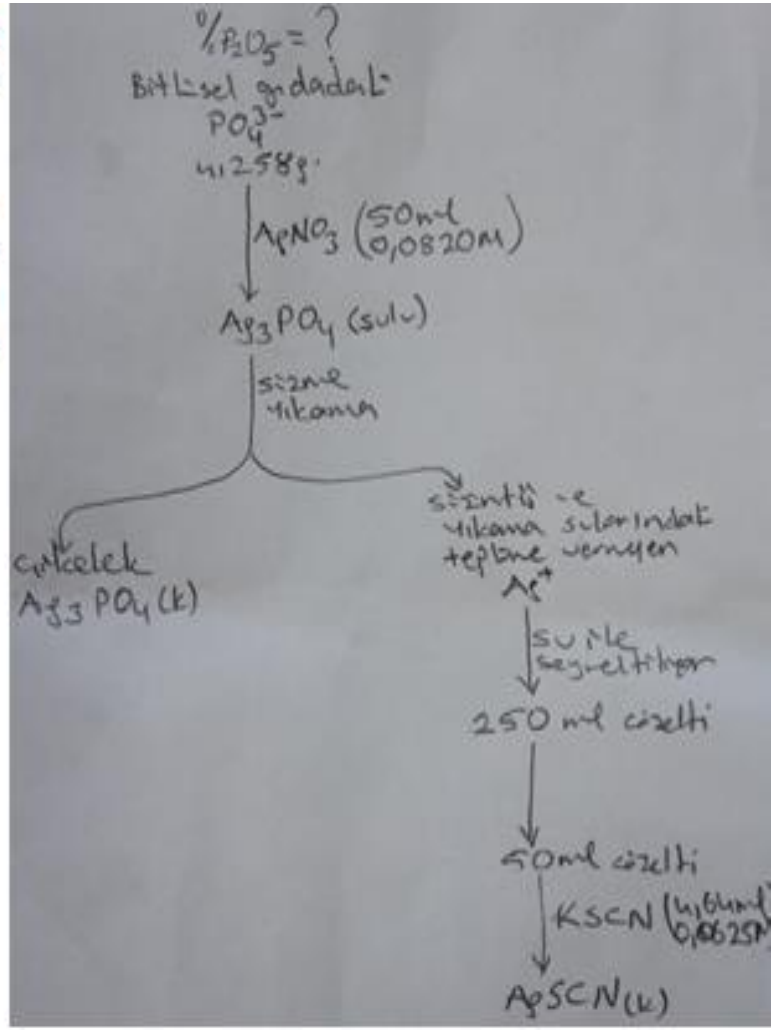

\section{Şekil 4. Volumetrik analiz/çöktürme titrasyonlarıyla ilgili problem ve problemin öğretiminde kullanılan akış şeması}

Şekil 4'de volumetrik analizlerden çöktürme titrasyonlarından volhard yöntemiyle ilgili problem ve probleme ait akış şeması verilmiştir. Problemde 4,258g numunedeki fosfat $50 \mathrm{ml}$ $0,0820 \mathrm{M} \mathrm{AgNO}_{3}$ ile titre edildiğinde gümüş fosfat $\left(\mathrm{Ag}_{3} \mathrm{PO}_{4}\right)$ şeklinde çöktürüldügü, süzme, yıkama vb. bir dizi deneysel işlemlerden geçtiği, 250 ml'ye seyreltildiği, çözeltinin 50 ml'sinin potasyum tiyosiyanür (KSCN) ile titre edildiği akış şemasında gösterilmiştir. Ayrıca beşte bir oranında alınan süzüntü ve yıkama sularındaki tepkimeye girmeyen ve ortamda kalan $\mathrm{AgNO}_{3}$ '’n

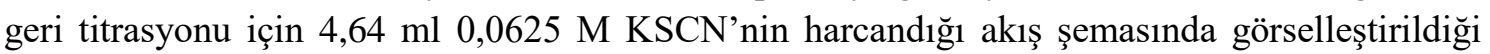
için problemin öğretimini kolaylaştırılmıştır. 
$\left(\mathrm{NH}_{4}\right)_{2} \mathrm{SO}_{4}, \mathrm{NH}_{4} \mathrm{NO}_{3}$ ve inert maddeleri içeren $1,219 \mathrm{~g}$ 'lk bir numune bir ölçülü balonda $200 \mathrm{~mL}$ 've seyreltiliyor. Alınan 50,00 mL'lik bir kisım kuvvetli bir bazla bazik yapiliyor ve açığa çıkan $\mathrm{NH}_{3} 30,00$ $\mathrm{mL} 0,0842 \mathrm{M} \mathrm{HCl}$ içine damitliyor. HCl'nin aşırıs için $10,17 \mathrm{~mL} 0,08802 \mathrm{M}$ $\mathrm{NaOH}$ harcaniyor. Numuneden alınan 25,00 mL'lik bir kısm ise Devarda alaşımı ilave edilerek $\mathrm{NO}_{3}$ - iyonu $\mathrm{NH}_{3}$ 'e indirgendikten sonra bazik yapiliyor. Sonra hem $\mathrm{NH}_{4}{ }^{+}$hem de $\mathrm{NO}_{3}$ dan oluşan amonyak $30,00 \mathrm{~mL}$ standart asit içine damituliyor ve $14,16 \mathrm{ml}$ baz ile geri titre ediliyor. Numunedeki $\left(\mathrm{NH}_{4}\right)_{2} \mathrm{SO}_{4}$ ve $\mathrm{NH}_{4} \mathrm{NO}_{3}$ 'in yüzdelerini hesaplayınız.

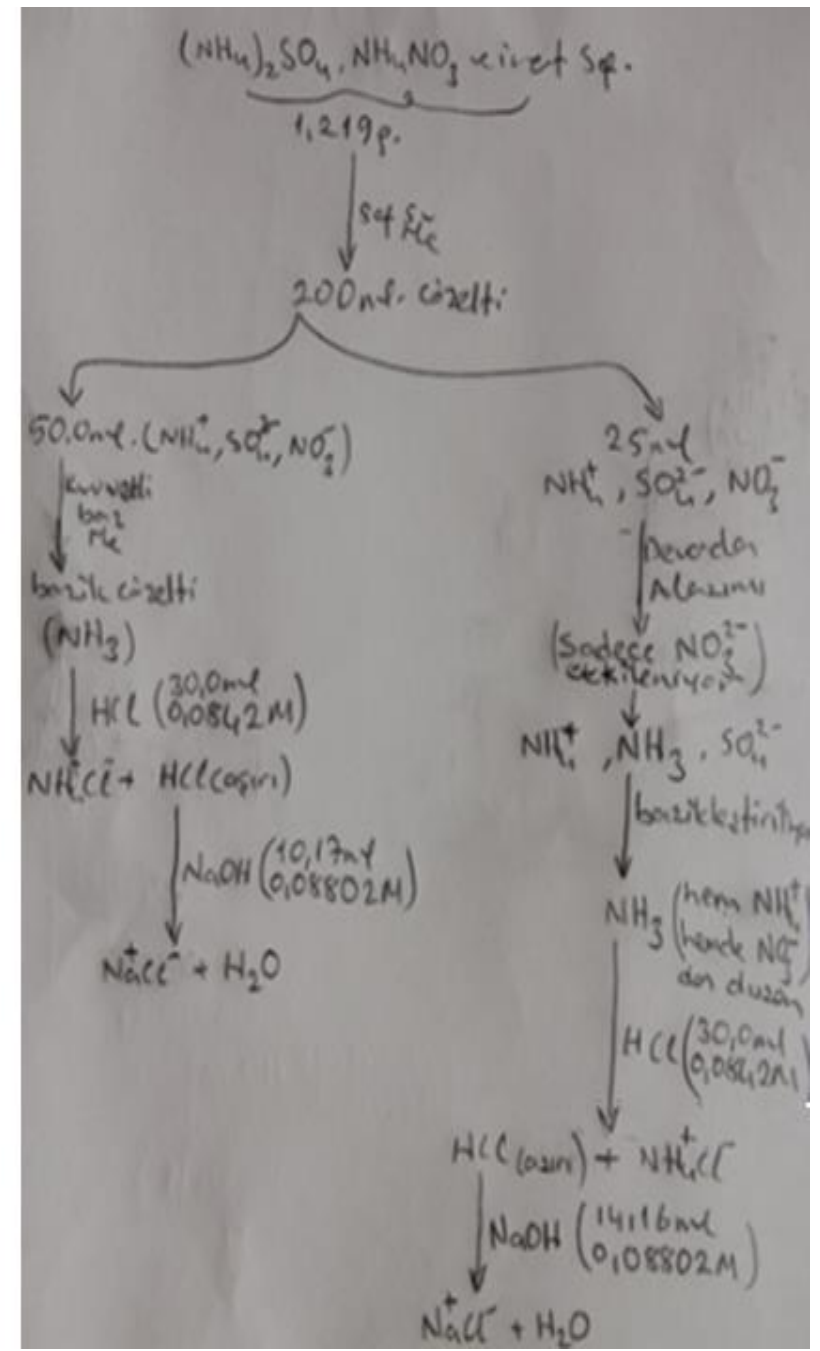

Şekil 5. Volumetrik analiz/asit-baz titrasyonlarıyla ilgili problem ve problemin öğretiminde kullanılan akış şeması

Şekil 5 incelendiğinde katyonu ayn $1\left(\mathrm{NH}_{4}{ }^{+}\right)$anyonu farklı $\left(\mathrm{SO}_{4}{ }^{2-}, \mathrm{NO}_{3}{ }^{-}\right)$olan amonyum sülfat $\left(\mathrm{NH}_{4}\right)_{2} \mathrm{SO}_{4}$ ve amonyum nitrat, $\left(\mathrm{NH}_{4} \mathrm{NO}_{3}\right)$ tuzları ile bir miktar inert madde içeren bir numunenin sulu çözeltisinden bir miktar $(200 \mathrm{ml})$ alınarak iki kısımda analiz edilmektedir. Şekil 5'deki problem Şekil 3'deki probleme benzer gibi gözükse de Şekil 3 gravimetrik analizi içerirken Şekil 5 volumetrik analizi içermektedir. Şekil 5'de aranan maddelerin yanında inert madde bulunurken Şekil 3'de yoktur. Şekil 3'de her iki kısmında alınan çözeltiler eşit miktarlarda $(50 \mathrm{ml})$ kullanılırken, Şekil 5'de birinci kısımda $50 \mathrm{ml}$ ikinci kısımda $25 \mathrm{ml}$ kullanılmıştır. Ayrıca problem Şekil 4'deki problemde olduğu gibi tepkimeye girmeyen maddenin geri titrasyonu içerdiği, geri titrasyonda hidroklorik asidin $(\mathrm{HCl})$ sodyum hidroksit $(\mathrm{NaOH})$ ile titre edildiği ve $14,16 \mathrm{ml} 0,08802 \mathrm{M} \mathrm{NaOH}$ 'in harcandı ̆̆ 1 görselleştirilerek açıklandığı için problemin öğretimini kolaylaştırmıştır. 
0,3284 g'lik bir pirinç numunesi (kurşun, çinko, bakır ve kalay içerir) nitrik asitte çözülüyor. $\mathrm{Az}$ çözünen $\mathrm{SnO}_{2} \cdot 4 \mathrm{H}_{2} \mathrm{O}$ süzülüyor ve süzüntü $500,0 \mathrm{~mL}$ 'ye seyreltiliyor.100 mL'lik bir kısim tamponlandiktan sonra kurşun, kalay ve bakir $37,56 \mathrm{~mL} 0,002500$ M EDTA ile titre ediliyor. 25,00 mL'lik bir kısimdaki bakır tivosülfat ile maskeleniyor; kurşun ve çinko $27,67 \mathrm{~mL}$ EDTA ile titre ediliyor. $100 \mathrm{~mL}$ 'lik bir kısımdaki bakır ve çinko siyanür ile maskeleniyor ve kurşun iyonların titre etmek için 10,80 $\mathrm{mL}$ EDTA çözeltisi saf ediliyor. Pirinç numunesinin bileşimini bulunuz; farktan kalayın yüzdesini hesaplayınız.

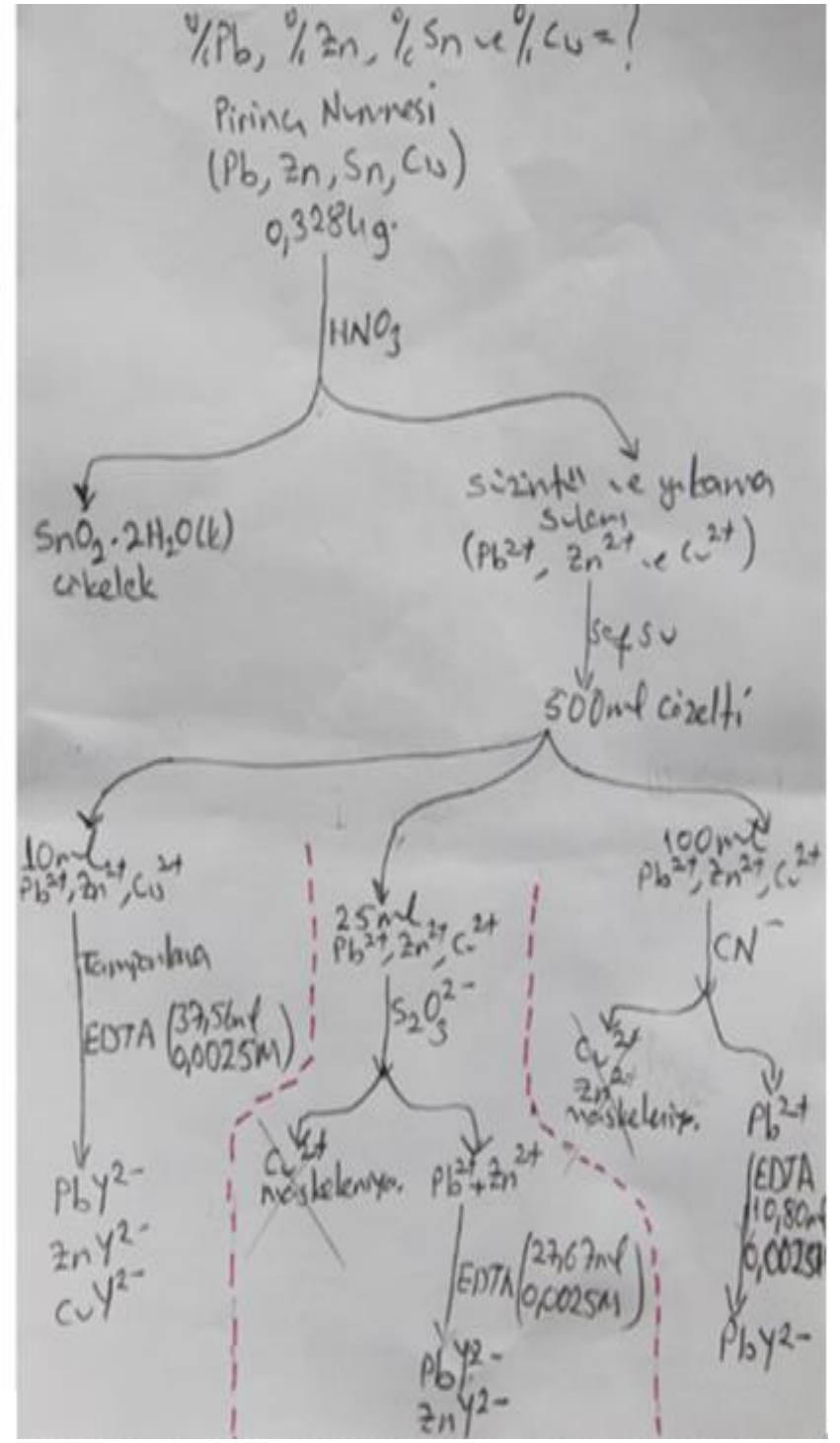

Şekil 6. Volumetrik analiz/kompleksleşme titrasyonlarıyla ilgili problem ve problemin öğretiminde kullanılan akış şeması

Şekil 6'da volumetrik analizlerden kompleks oluşumuna dayanan titrasyonlarla ilgili olup Şekil 1-5'deki problemlerden farklıdır. Şekil 6'da problem dört bileşenli bir karışım olup nitrik asit $\left(\mathrm{HNO}_{3}\right)$ ilavesinden sonra kalayın kalay (IV) oksit tetrahidrat $\left(\mathrm{SnO}_{2} \cdot 4 \mathrm{H}_{2} \mathrm{O}\right)$ halinde çökerek ayrıldığı ve geri kalan üç bileşenin çözeltide olduğu, üç ayrı kısımda farklı hacimdeki çözeltilerin etilendiamintetraasetikasit (EDTA) çözeltisiyle titre edildiği ve her birinde farklı işlem yapıldığı, EDTA'nın hangi metal iyonlarıyla kompleks oluşturduğu, maskeleme ile hangi katyonların maskelendiği ve EDTA'nın hangi katyonlar için ne kadar harcandığı akış şemasında görselleştirerek açıkladığı için problemin öğretimini kolaylaştırmıştır. 
0,09280 g'llk yanik merhemindeki organik madde yakildiktan sonra, $\mathrm{ZnO}$ 'li katı kalıntı asitte çözülüyor. Çözeltiye $(\mathrm{NH} 4)_{2} \mathrm{C}_{2} \mathrm{O}_{4}$ eklenerek az çözünen $\mathrm{ZnC}_{2} \mathrm{O}_{4}$ oluşturuluyor. $\mathrm{Bu}$ çökelek süzülüyor, yikaniyor ve sonra da tekrar seyreltik asitte çözülüyor. Oluşan $\mathrm{H}_{2} \mathrm{C}_{2} \mathrm{O}_{4} \quad 37,81 \mathrm{~mL}$ $0,01508 \mathrm{M} \mathrm{KMnO}_{4}$ ile titre ediliyor. İlaçtaki $\mathrm{ZnO}$ yüzdesini hesaplayınız.

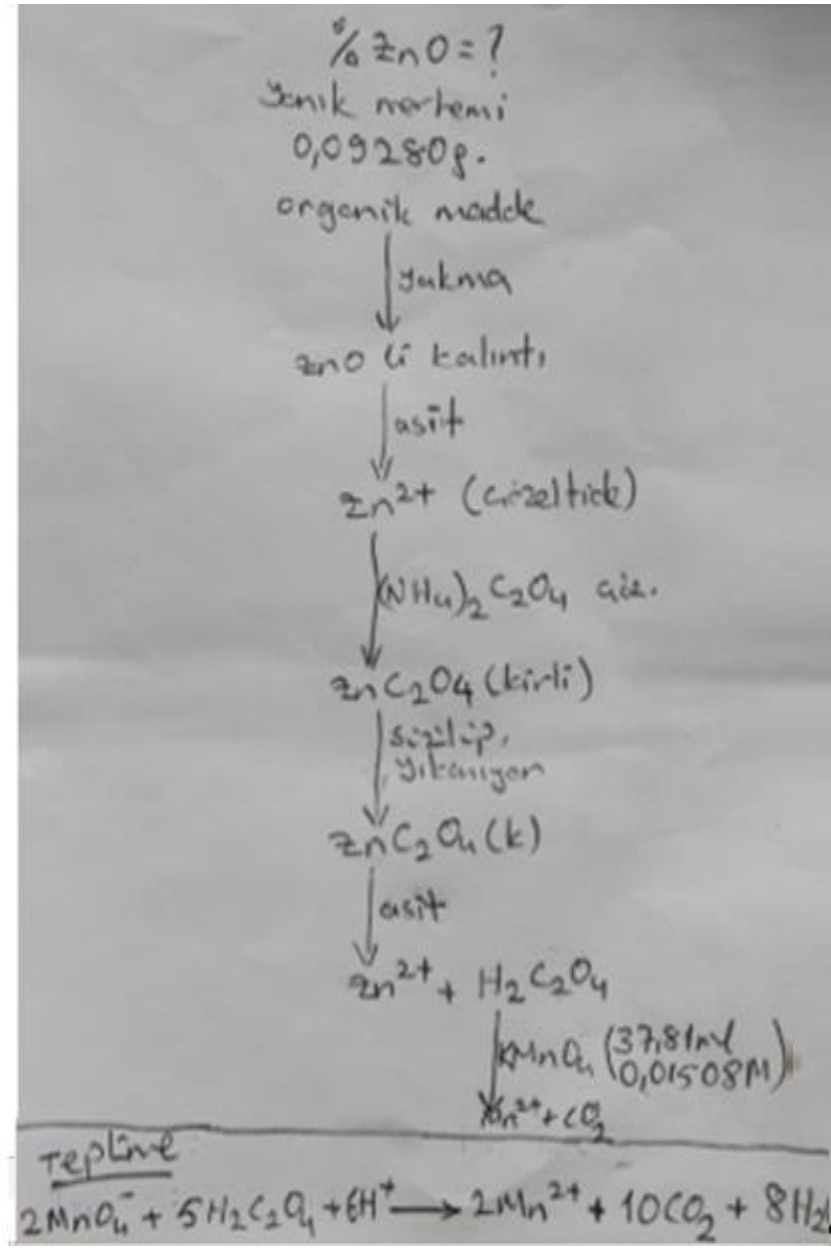

Şekil 7. Volumetrik analiz/redoks titrasyonlarıly ilgili problem ve problemin öğretiminde kullanılan akış şeması

Şekil 7'de volumetrik analizlerden redoks titrasyonlarıyla ilgili problem olup diğer problemler (Şekil 1-6) gibi karmaşık ve uzundur. Problemde 0,09280g yanık merhemindeki çinko oksit $(\mathrm{ZnO})$ asitte çözülüp oksalat $\left(\mathrm{C}_{2} \mathrm{O}_{4}{ }^{2-}\right)$ iyonuyla çöktürüldükten sonra oluşan çinko oksalatın $\left(\mathrm{ZnC}_{2} \mathrm{O}_{4}\right)$ asitte çözüldüğü ve oksalik asidin $\left(\mathrm{H}_{2} \mathrm{C}_{2} \mathrm{O}_{4}\right)$ permanganat iyonu $\left(\mathrm{MnO}_{4}{ }^{-}\right)$ile titre edildiği problemde verilmiş ancak Şekil 4'de olduğu gibi problem metninde tepkime denklemi verilmemiştir. Şekil 7'deki akış şemasında deneysel işlemler adım adım gösterildiği

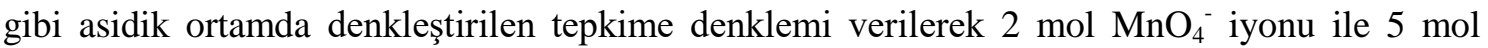
$\mathrm{C}_{2} \mathrm{O}_{4}{ }^{2-}$ iyonunun tepkime verdiği görselleştirilerek açıklandığı için problemin öğretimini kolaylaştırmışır.

\section{İkinci Alt Probleme İlişskin Bulgular}

Görüş formu ve yarı yapılandırılmış görüşmelerden elde edilen bulgular iki alt başlık altında verilmiştir.

\section{Görüş Formuna İlişkin Bulgular}

Katılımcıların akış şemalarına yönelik görüşlerini içeren açık uçlu tek sorudan oluşturulan kategori ve temalar tablolar halinde verilmiştir. 
Tablo 1. Katılımcıların Nicel Analizlerle İlgili Problemlerin İçeriğine Yönelik Görüşleri

\begin{tabular}{lccc}
\multicolumn{1}{c}{ Tema } & Katıllımc1lar & $f$ & $\%$ \\
\hline Uzun ve karmaş1k & Ö1, Ö3, Ö4, Ö5, Ö8, Ö11 & 6 & 46 \\
Kafa karıştırıc1 & Ö3, Ö11, Ö12, Ö13 & 4 & 31 \\
Deneysel işlemleri içerme & Ö3, Ö4, Ö13 & 3 & 23 \\
\hline
\end{tabular}

Tablo 1'de, öğretmen adaylarının \%46'sı problemlerin uzun ve karmaşık, \%30'u kafa karıştırıcı ve \%24'ü deneysel işlemler içerdiğini belirtmiştir.

Tablo 2. Katılımcıların Nicel Analizlerle İlgili Problemlerin Çözümünde Akış Şemasını Çizme Süresine Yönelik Görüş̧leri

\begin{tabular}{lccc}
\multicolumn{1}{c}{ Tema } & Kat1lımc1lar & $f$ & $\%$ \\
\hline Zaman1 etkili kullanma & Ö1, Ö2, Ö3, Ö4, Ö5, Ö7, Ö10, Ö11, Ö12, Ö13 & 10 & 76 \\
Sinavlarda ek zaman ayırma & Ö8, Ö9 & 2 & 16 \\
\hline
\end{tabular}

Tablo 2'de, öğretmen adaylarının \%76'sı zamanı etkili kullanıldığını, \%16'sı sınavlarda zaman alıcı olduğunu belirtmiş, adaylardan biri (Ö6) herhangi bir yorum yapmamıştır.

Tablo 3. Katılımcıların Nicel Analizlerle İlgili Problemlerin Çözümlerine Akış Şemalarının Katkısına Yönelik Görüşleri

\begin{tabular}{|c|c|c|c|}
\hline Tema & Katılımcilar & $f$ & $\%$ \\
\hline Çözümü kolaylaştırma & Ö1, Ö2, Ö3, Ö4, Ö5, Ö6, Ö7, Ö10, Ö11 & 9 & 69 \\
\hline Doğru çözüme ulaşma & Ö1, Ö6, Ö7, Ö8, Ö10, Ö11, Ö13 & 7 & 54 \\
\hline Ne yapacağını anlama & Ö1, Ö2, Ö3, Ö7, Ö10, Ö12 & 6 & 46 \\
\hline Yorumlama gücünü artırma & Ö2, Ö3, Ö10, Ö12, Ö13 & 5 & 38 \\
\hline Soruyu basitleştirme & Ö8, Ö10, Ö11, Ö12, Ö13 & 5 & 38 \\
\hline Soruyu tanımada etkili olma & Ö5, Ö8, Ö9, Ö10, Ö13 & 5 & 38 \\
\hline İşlem yapılacak basamakları gösterme & Ö3, Ö4, Ö13 & 3 & 23 \\
\hline Hata yapma olasılığını azaltma & Ö4, Ö7, Ö9 & 3 & 23 \\
\hline Kendine güvenme & Ö9, Ö11, Ö13 & 3 & 23 \\
\hline Yol gösterici olma & Ö1, Ö13 & 2 & 15 \\
\hline Faydalı ve işe yarama & Ö4, Ö6 & 2 & 15 \\
\hline
\end{tabular}

Tablo 3'de öğretmen adaylarının \%69'u problemlerin çözümünü kolaylaştırdığı, \%54'ü doğru çözüme ulaştırdığı, \%46'sı anlamayı sağladığı vb. olumlu görüşleri mevcuttur.

Yarı yapılandırılmış görüşmelere ilişkin bulgular

Tablo 4. Yarı Yapılandırılmış Görüşmede Gönüllü Öğretmen Adaylarının Yanıtları

\begin{tabular}{|c|c|c|}
\hline Soru & Yanit & $f$ \\
\hline 1 & "Hayır" & 4 \\
\hline \multirow{2}{*}{2} & "Etkisi çok iyi oldu." & 2 \\
\hline & "Çok oldu." & 2 \\
\hline \multirow{8}{*}{$3 *$} & "Bu kadar iyi anlayamazdık." & 1 \\
\hline & Başka problemlerle ilişki kuramazdık & 1 \\
\hline & Neyi nasıl yapacağımızı net göremezdik." & 1 \\
\hline & "Anlaşılmazdı." & 1 \\
\hline & "Çözümüne nereden ve nasıl başlayacağımızı bilemezdik." & 1 \\
\hline & “Okurken sıkılabilirdik." & 1 \\
\hline & "Çözemeyecek korkusunu yaşayabilirdik" & 1 \\
\hline & "Okurken kafamız karışabilirdi" & 1 \\
\hline 4 & "Hayır" & 4 \\
\hline 5 & "Evet" & 4 \\
\hline 6 & "Evet" & 4 \\
\hline 7 & "Evet" & 4 \\
\hline
\end{tabular}

*Birden fazla yanıt 
Problemlerin anlaşılmasında akış şemalarının kullanılmasına yönelik katılımcı görüşlerinin olumlu olduğu belirlenmiştir. İkinci ve üçüncü soru hariç diğer soruların Evet/Hayır şeklinde yanıtlandığı, en fazla farklı görüş "Problemler problem çözme yöntemine göre değil de klasik yönteme göre çözülmüş olsaydı problemleri anlama ve kavrama düzeyininiz nasıl olurdu?" sorusunda olduğu Tablo 4'de görülmektedir.

$\mathrm{KCl}, \mathrm{K}_{2} \mathrm{SO}_{4}$ ve inert safsızlik içeren $2,4414 \mathrm{~g}$ 'llk bir numune $250,0 \mathrm{~mL}$ 'lik çözelti elde edilecek şekilde suda çözülüyor. 50,0 mL'lik kısmı için Mohr titrsvonunda 41,36 $\mathrm{mL} 0,05818 \mathrm{M} \mathrm{AgNO}_{3}$ harcaniyor. İkinci bir $50,00 \mathrm{~mL}$ 'lik kismi 40,00 mL 0,1083 M $\mathrm{NaB}\left(\mathrm{C}_{6} \mathrm{H}_{5}\right)_{4}$ ile muamele ediliyor. Reaksiyon şöyledir:

$\mathrm{NaB}\left(\mathrm{C}_{6} \mathrm{H}_{5}\right)_{4}+\mathrm{K}^{+} \rightarrow \mathrm{KB}\left(\mathrm{C}_{6} \mathrm{H}_{5}\right)_{4}(\mathrm{k})+\mathrm{Na}^{+}$ Oluşan katı süzülüyor, asetonda çözülüyor ve $49,98 \mathrm{~mL} \mathrm{AgNO}_{3}$ çözeltisi ile titre ediliyor.

$\mathrm{KB}\left(\mathrm{C}_{6} \mathrm{H}_{5}\right)_{4}+\mathrm{Ag}^{+} \rightarrow \mathrm{AgB}\left(\mathrm{C}_{6} \mathrm{H}_{5}\right)_{4(\mathrm{x})}+\mathrm{K}^{+}$ Numunedeki $\mathrm{KCl} \quad \mathrm{K}_{2} \mathrm{SO}_{4}$ yüzdelerini hesaplayiniz.

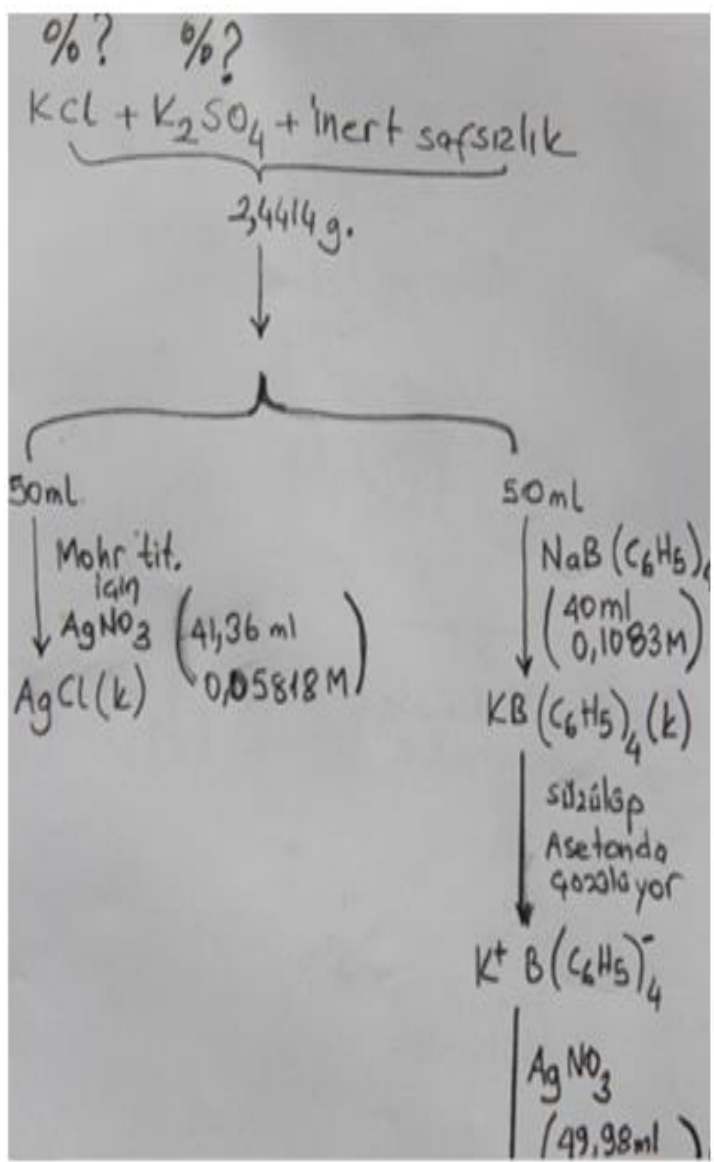

Şekil 8. Yarı yapılandırılmış görüşsmede verilen problem metni ve bir öğretmen adayının çizdiği akış şeması

Yarı yapılandırılmış görüşmede katılımcılara 5. Soru ("Nicel analiz ile ilgili herhangi bir problem verilmişs olsa akış şemasını çizebilir misiniz?") yöneltildiğinde "Evet" yanıtının alınması üzerine Şekil 8'deki problem metni verilmiş ve katılımcıların metnindeki işlem basamaklarını adım adım göstererek akış şemasını çizebildikleri belirlenmiştir (Şekil 8). Benzer şekilde katılımcılara 6. Soru ("Nicel analiz ile ilgili herhangi bir problemin akış şeması verilmiş olsa probleme ait metni yazabilir misiniz?") yöneltildiğinde "Evet” yanıtı alınmış, Şekil 9'daki akış şeması verildiğinde akış şemasına göre problem metnini yazabildikleri, benzer kelime ya da cümleler olmasa da anlam bakımından aynı olduğu belirlenmiştir. Ayrıca katılımcılara öğretmen olduklarında problem çözümlerinde akış şeması kullanacaklarına yönelik görüşlerinin görüş formundaki temalara benzer olduğu tespit edilmiştir. 


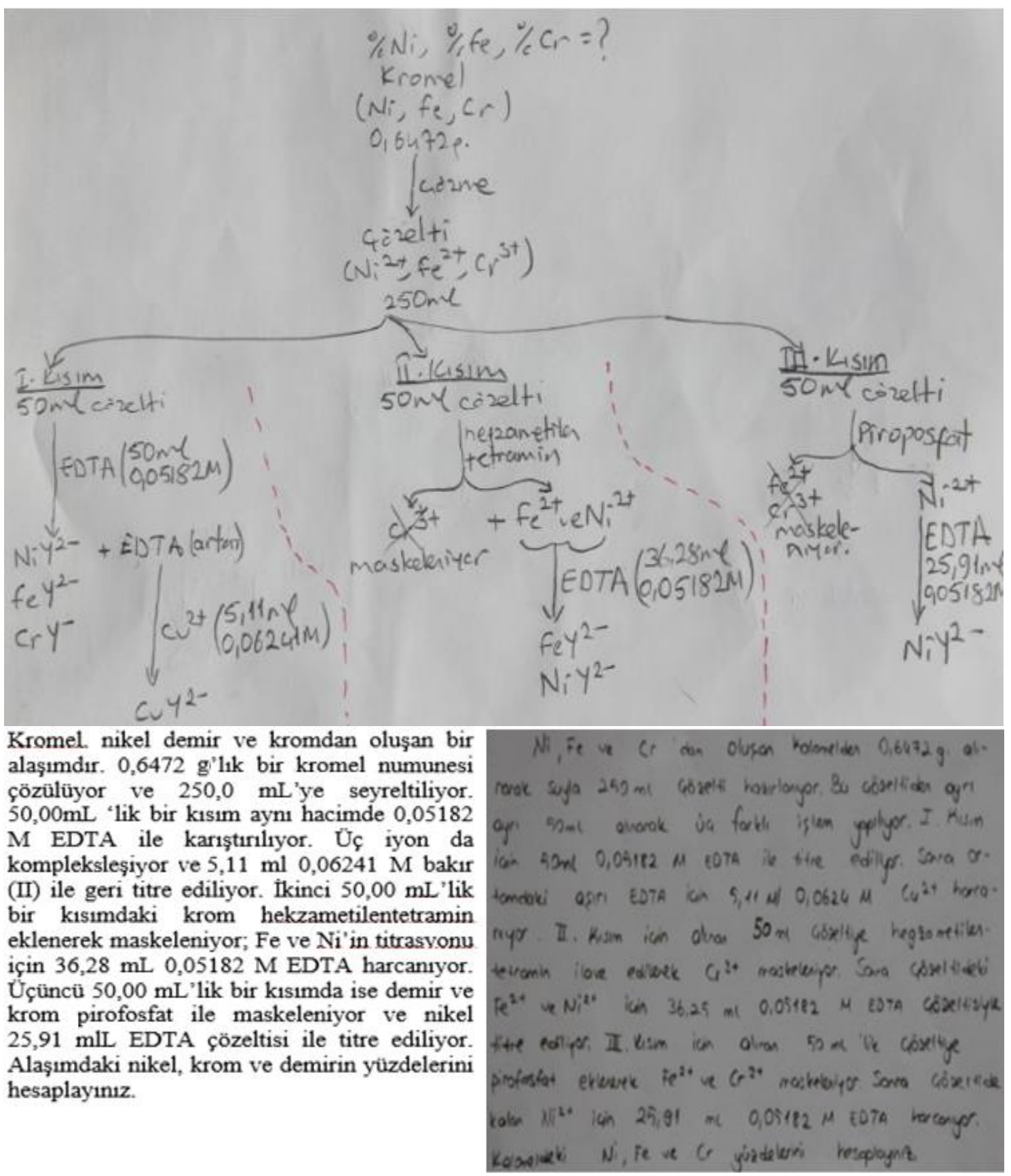

Şekil 9. Yapılandırılmış görüşmede verilen akış şeması, akış şemasına göre bir öğretmen adayının yazdığı problem metni ve problemin kaynak kitaptaki asıl metni

\section{Tartışma ve Sonuç}

Kimyanın anabilim dallarından Analitik Kimya bir numunedeki bileşenlerin bağıl miktarlarının analizlerinin yanında ayırma ve teşhisiyle de ilgilenmektedir. Nitel (kalitatif) ve nicel (kantitatif) olarak ikiye ayrılır. Nitel analiz, numunedeki türlerin kimyasal olarak belirlenmesi ile uğraşırken; nicel analiz, bir veya daha fazla tür ya da maddedeki bileşenlerin bağıl miktarlarının sayısal olarak belirlenmesidir (Skoog, West \& Holler, 1996). 
Nicel analiz problemlerinde bir dizi önemli analiz basamakları bulunmaktadır (Gündüz, 1992). Ayrıca problem metinleri içerisinde sayısal verilerin yanında deneysel işlem basamakları da verilebildiğinden (Şekil 1-9) problem metinleri çoğunlukla karmaşık ve uzundur. Öğrenciler problem metninin uzunluğundan psikolojik olarak etkilenip çözümünün zor olacağını düşünerek okumaktan vazgeçebilirler. Nitekim katılımcılarla yapılan yüz yüze görüşmelerde "Derste aklş şeması çizilmeden problemler çözülmüş olsaydı problemleri anlama ve kavrama düzeyininiz nasıl olurdu?" sorusuna verilen yanitlarından problemi okurken çözümüne nereden ve nasıl başlayacaklarını bilemeyecekleri, uzun olduğu için okumaktan vazgeçecekleri, problemi çözemeyecek korkusunu yaşayacakları, okurken kafalarının karışacakları vb. görüşlerinin olduğu belirlenmiştir.

Uzun metin içeren problemleri (Şekil 1-9) okuyup çözmeye başlayan öğrenciler problem metninin içindeki sayısal tüm verileri kullanacaklarını düşünebilirler. Ancak deneysel işlemleri içeren nicel analiz problemlerinde her sayısal veri problemin çözümünde gerekli olmayabilir ya da her basamakta oluşan ürün için sayısal veri bulunmayabilir. Örneğin, Şekil 1'deki akış şemasında hangi verinin deneysel işlem basamaklarını anlattığı, hangi verinin problemin çözümü için gerekli olduğu görülebilir. Çünkü Şekil 1'deki akış şemasında reaktif $\left(\mathrm{CdCl}_{2}\right)$ ilavesinden sonra oluşan CdS'ün bir dizi gravimetrik analizin deneysel işlemler (süzme, yıkama, 1sıtma ve yakma) sonucunda $\mathrm{CdSO}_{4}{ }^{\prime}$,a dönüştüğünü görselleştirerek açıklandı̆̆ 1 için problemin anlaşılmasının kolaylaştırıldığı, anlamlı ve kalıcı öğrenme sağlandığ düşünülmektedir. Bu düşünceyi katılımcıların görüş ve düşüncelerinin (Tablo 1-4) desteklediği söylenebilir.

Nicel analizle ilgili problemlerde bazen karışımı oluşturan tuzlar aynı anyon ya da katyonları içerdiği gibi farklı anyon ya da katyonları da içerebilir. Hatta bunların yanında inert maddelerde bulunabilir ve çoğu problemde olduğu gibi nicel analiz işlemleri birden fazla kısımda da yapılabilir. Öğrencilerin problemin hangi kısımda hangi maddenin analizinin yapıldığını fark edebilmeleri için problemi çok iyi anlamaları ve çözüm için gerekli olan sınırları belirlemelidir. Örneğin Şekil 2'deki akış şeması problemin anlaşılmasını kolaylaştırmasının yanında gravimetrik analizdeki işlem basamaklarının da pekiştirildiği söylenebilir. Çünkü öğrencilerin problemi anlayabilmeleri için gümüş halojenür çökeleğindeki gümüş iyodürün $(\mathrm{AgI})$ klor $\left(\mathrm{Cl}_{2}\right)$ gazı akımından sonra $\mathrm{AgCl}$ 'e dönüştüğünü, numunedeki klorürden oluşan $\mathrm{AgCl}$ 'ün etkilenmeden çökelekte kaldığını ve sonunda oluşan çökeleğin tamamının $\mathrm{AgCl}$ 'den ibaret olduğunu fark etmeleri sağlanmalıdır. Aksi takdirde problemin anlaşılması yeterli düzeyde olmayacağı ve anlamlı öğrenme gerçekleşmeyeceği söylenebilir. Ayrıca Şekil 2'de numunenin iki bileşenli olması ve her adımda oluşan maddelerin kütlelerinin verilmesi Şekil 1'deki problemin çözümüne benzer bir çözümle ulaşamayacaklarının da farkına varabilirler. Benzer şekilde öğrenciler Şekil 3'deki problemin çözümünü Şekil 2'deki gibi düşünüp çözmeye kalkışırlarsa hata yapma olasılıkları artabilir. Çünkü Şekil 3'deki problemde numune bileşenlerinin çözelti ortamına alındığı ve analiz için çözeltinin onda birinin kullanıldığına dikkat etmeleri sağlanmalıdır. Nitekim Şekil 3'de numuneden kaç ml çözelti hazırlandığı, birinci ve ikinci kısımdaki analizlerde kaçar ml kullanıldığı, 0,5923g AgCl sadece çözeltinin onda birinin kullanılmasıyla oluştuğu, oluşan $\mathrm{AgCl}$ numunedeki hem $\mathrm{MgCl}_{2}$ 'den hem de $\mathrm{NaCl}$ 'den çözeltiye geçen klorür iyonun $\mathrm{AgNO}_{3}$ ile çöktürülmesinden oluştuğu gibi bilgiler akış şemasında gösterilmiştir. Ayrıca öğrenciler Şekil 3'deki problemin ikinci kısmında çözeltinin onda birinde $0,1796 \mathrm{~g} \mathrm{Mg}_{2} \mathrm{P}_{2} \mathrm{O}_{7}$ 'ın numunedeki $\mathrm{MgCl}_{2}$ 'den kaynaklandığını fark 
edemezlerse problemi çözerken hata yapma olasılıklarının artacağı söylenebilir. Benzer şekilde hesaplama sırasında gravimetrik ve seyreltme faktörleri dikkate almadan problemi çözmeye kalkışırlarsa yine hata yapma olasılıkları artacaktır. Bütün bunlara dikkat etmek, adım adım işlemleri kavratmak ve hata yapma olasılığını azaltmak için problemlerin öğretimini kolaylaştıran akış şemasının çizilmesinin yararlı olduğu düşünülmektedir. Bu düşünceyi katılımcı görüşlerinden akış şeması çizmekle kafa karışıklığının giderildiği, problemlerin anlaşılması ve kavranmasını kolaylaştırdığı, problem çözmeyi eğlenceli hale getirdiği ve daha kısa sürede problemlerin çözülebildiği vb. olumlu görüşlerinin (Tablo 1-4) desteklediği söylenebilir.

Şekil 4'deki vb. yöntemin uygulanmasına dayanan nicel analiz problemlerin çözümünde yaşanacak sorunların azaltılması veya tamamen ortadan kaldırılması için akış şemalarının kullanılmasının yararlı olacağı düşünülmektedir. Çünkü Şekil 4'deki akış şemasında Volhard yönteminin işlem basamakları adım adım gösterildiği için öğrenciler sadece problemi anlamakla kalmayıp Volhard yöntemine göre titrasyonun nasıl ve hangi amaçlarla yapıldığının da farkına varabilirler. Ayrıca problemde (Şekil 4) harcanan potasyum tiyosiyanür (KSCN) beşte bir oranda alınan süzüntü ve yıkama sularındaki tepkimeye girmeyen ve ortamda kalan $\mathrm{AgNO}_{3}{ }^{\prime}$ 'n geri titrasyonu için kullanıldığını fark edemezlerse problemin çözümü sırasında hata yapma olasılıkları artabilir. Çizilen akış şemasında (Şekil 4) her bir işlem adım adım net olarak gösterildiğinden problemin çözümünün yapılabilirliğini artıracağı ve hata yapma olasılığını azaltacağı düşünülmektedir. Ayrıca akış şeması ile tepkimeye girmeyen ve ortamda aşırı kalan $\mathrm{AgNO}_{3}$ 'ı $\mathrm{KSCN}$ ile geri titre edildiğini görselleştirerek açıklandığı için akış şeması problemin sadece anlaşılmasını kolaylaştırmakla kalmayıp aynı zamanda doğru sonuca ulaşma olasılığını da artıracağı söylenebilir. Nitekim kavram haritalama çeşitleri (hiyerarşik, akış şeması, örümcek vb.) öğrencilerin anlamlı öğrenmesini sağlamakta ve başarılarını artırmaktadır (Altun ve Arslan, 2006; Bamidele \& Oloyede, 2013; DiCaprio, 1981; Van Domelen, 2006; Hicks \& Bevsek, 2012; Novak \& Canas, 2006; Waddling,1983).

Şekil 3 ve 4'deki problemlerin akış şemalarını anlamlı öğrenen ve problemin çözümünü yapan bir öğrenci, Şekil 5'deki problemle ilişki kurabilir, problemin anlaşılmasını kolaylaştırabilir ve problemdeki geri titrasyonun hangi amaçla yapıldığını kavrayabilir. Belki de bir titrasyonda geri titrasyonun hangi amaçlarla yapıldığını ve problemde "Geri titre edilir" ifadesi gibi geri titrasyona atıf yapan bir cümle bulunmasa da o işlemin geri titrasyon olduğunu fark edebilir. Çünkü Şekil 5'deki problem Şekil 4'deki problemde olduğu gibi ortamda tepkime vermeden aşırı kalan maddenin $(\mathrm{HCl})$ geri titrasyonunu içermektedir. $\mathrm{Bu}$ açıdan bakıldığında nicel analiz problemlerin öğretiminde akış şemalarının kullanılması aynı zamanda kavram öğretimini de kolaylaştıracağını düşündürmektedir. Nitekim katılımcıların geri titrasyonun neden yapıldığı, hangi işlemin geri titrasyon olduğunu ve problemde harcanan reaktifin ne kadarının numune için harcandığını akış şeması görselleştirerek açıkladığı için daha iyi kavradıklarını belirtmeleri Analitik Kimya II dersindeki nicel analiz problemlerini çözmeden önce akış şemasının çizilmesinin iyi olduğunu düşündürmektedir. DeCaprio'ya (1981) göre, bir problemi çözmeye başlamadan önce güçlü ve verimli bir yöntem kullanmanın yolu akış şemasının hazırlanmasıdır.

Şekil 3, 4 ve 5'deki problemlerin çözümünü anlamlı öğrenen öğrenciler Şekil 6'daki problemde doğru sonucu ulaşma olasılıklarını artacağı düşünülmektedir. Çünkü Şekil 6'daki 
problem Şekil 3, 4 ve 5' deki gibi nicel analiz birkaç kısımdan oluşmaktadır. Öğrenciler akış şemasından hangi kısımda hangi bileşen ya da bileşenler için EDTA çözeltisinin harcandığını fark ederek nasıl ilişki kuracaklarını ve problemin çözümüne nasıl ulaşacaklarını kolaylıkla anlayabilir ve doğru sonuca ulaşma olasılıkları artabilir. Çünkü problemde çöktürme işlemi ile çözeltideki kalayın $\mathrm{SnO}_{2} \cdot 4 \mathrm{H}_{2} \mathrm{O}$ şeklinde çözeltiden ayrıldığı, çözeltide geri kalan üç bileşenin EDTA çözeltisiyle titre edildiği ve her adımda farklı işlem yapıldığı, EDTA'nın hangi metal iyonlarıyla kompleks oluşturduğu ve maskeleme yapılarak titre edilebildiği görülebilir (Şekil 6). Böyle bir problemde öğrenciler sadece problemin çözümüne ulaşmakla kalmayıp EDTA çözeltisiyle yapılan titrasyon uygulamalarıyla ilgili bilgilerini de pekiştirmiş olurlar. Ayrıca Şekil 6'daki akış şeması ile çözeltide birden fazla katyon bir arada olsa bile EDTA ile titre edilebildiği, EDTA'nın kompleks oluşumuna dayanan titrasyonlarda neden daha fazla kullanıldığı ve önemli bir reaktif olduğunun farkına varabilirler. Çünkü kompleks oluşumuna dayanan titrasyonlar daha çok şelatlar olarak adlandırılan özel koordinasyon bileşikleriyle ilgili olup en fazla kullanılanı 6 dişli ligant EDTA'dır. Özellikle EDTA katyonun yükü ne olursa olsun metal iyonlarıyla $1 / 1$ oranında kompleks oluşturduğundan değerlidir. EDTA sadece katyonlarla şelat oluşturması değil aynı zamanda bu şelatların çoğunun titrimetrik yöntemin esasını oluşturacak kadar kararlı olduğu için de önemli bir reaktif (Gündüz, 1992) olduğunu kavrayabilirler. Ayrıca öğrenciler EDTA titrasyonu ile çözeltide birden fazla (örneğin 25) katyon olduğunda çözeltinin pH'sının ayarlanması, maskeleme yapılması veya maske kaldırılması işlemleri uygulanarak metallerin tayininin mümkün (Gündüz, 1992) olduğunu öğrenmiş olurlar.

Şekil 7'deki problem Şekil, 4, 5 ve 6'daki problemler gibi volumetrik analizi içermektedir ve diğer problemlerden biraz farklı olsa da reaktifin derişimi ve hacmi gibi benzerlikler bulunmaktadır. Problemin metninde (Şekil 7) redoks tepkimesini içerdiğine yönelik herhangi bir ifade olmaması ve tepkime denkleminin verilmemesi öğrencilerin hata yapma olasılığını artırabilir. Ayrıca Şekil 6'da olduğu gibi $\mathrm{MnO}_{4}{ }^{-}$ile $\mathrm{C}_{2} \mathrm{O}_{4}{ }^{2-}$ iyonlarının $1 / 1$ oranda tepkime vereceğini düşünerek çözmeye kalkışırlarsa hata yapmaları kaçınılmaz olur. Çünkü Şekil 7'de verilen denkleştirilmiş tepkime incelendiğinde $2 \mathrm{~mol} \mathrm{MnO}_{4}{ }^{-}$iyonu ile $5 \mathrm{~mol} \mathrm{C}_{2} \mathrm{O}_{4}{ }^{2-}$ iyonunun tepkime verdiği görülebilir. Böylece öğretmen adayları Şekil 7'deki akış şeması ile asidik ortamda redoks tepkimesinin nasıl denkleştirildiğiyle ilgili bilgi, beceri ve deneyimi pekiştirecekleri gibi tepkimedeki stokiyometriye göre problemin nasıl çözüleceğini de öğrenmiş olurlar. Hafsah, Rosnani, Zurida, Kamanuzaman \& Khoo'a (2014) göre, öğrencilerin problemlerin çözümünde öncelikle stokiyometrinin temelini oluşturan kavramsal bilgiyi anlamları için yönlendirilmeleri gerektiğini belirtmişlerdir. Bu konuda öğreticilere büyük yük ve sorumluluk düşmektedir. Örneğin Okanlawon (2010), öğretmenlerin tepkime stokiyometrisini anlama ve öğretimi hakkında yeterli bilgiye sahip olmadıklarını açıklamıştır. Gelbal (1991), öğrencilerin problem çözme başarısında öğretmenlerin önemli rol oynadığını, örnek problem çözümlerinin öğrenci başarısında etkili olduğunu, yeni örneklerin öğretmen yardımıyla çözülmesinin başka problemlerin çözümüne de katkı sağlayabileceğini belirtmiştir.

Katılımcıların problem metnine göre akış şemasını çizebilmesi (Şekil 8) veya akış şemasına göre problem metnini yazabilmeleri ders sırasında çizilen akış şemalarının problemin öğretimini kolaylaştırmada etkili olduğunu düşündürmektedir. DeCaprio'ya (1981) göre, akış şemaları bir problemin nasıl çözüleceğine veya bir görevi nasıl yerine getireceğine yönelik bir taslaktır ve sadece şemayı oluşturan problemi çözmekle kalmayacak diğer öğrencilerin de 
prosedürü takip ederek çözmesini sağlayacaktır. Gelbal (1991), öğrencilerin problem çözme davranışlarını geliştirmek için öğretmenlerin sınıfta çok fazla örnek problem çözmeleri gerektiğini belirtmişlerdir. Hicks \& Bevsek (2012), çevre kimyası laboratuvarında bir dizi nitel analizi içeren deneylerde öğrencilere rehberlik edecek bir modülü probleme dayalı öğrenme yöntemine göre hazırlamışlar ve öğrencilerden bu modülü kullanarak kirli suyun temizlenmesini açıklayan bir akış şemasını tasarlamalarını ve akış şemasının bileşimi bilinmeyen sulu katyon çözeltisinden katyonların ayrılmasını gösterecek şekilde olmasını istedikleri çalışmada, araştırmacılar hazırladıkları modülün faydalı olduğunu ve laboratuvarda nitel analizleri etkili şekilde öğretmek için alternatif olacağını belirtmişlerdir.

Nicel analiz problemlerinin öğretiminde akış şemalarının kullanılmasına yönelik öğretmen adaylarının görüşlerinden ulaşılan sonuçlar Analitik Kimya II dersi ve katılımcılar açısından aşağıda özetlenmiştir.

Analitik Kimya II dersi açısından;

$\checkmark$ Geleneksel yöntem yerine çağdaş yöntem ve tekniğin kullanılmasının iyi olduğu,

$\checkmark$ Dersin işlenişinde öğrencilerin aktif katılımının sağlandığ 1 ,

$\checkmark$ Öğretmen merkezli yerine öğrenci merkezli bir ders işlendiği,

$\checkmark$ Öğretme-öğrenme sürecini kısalttı̆̆

$\checkmark$ Problemlerin anlaşılmasını kolaylaştırdığı,

$\checkmark$ Anlamlı ve kalıcı öğrenmeyi sağladı̆̆ı,

$\checkmark$ Problemlerin eğlenerek çözüldüğü,

$\checkmark$ Etkili ve verimli bir ders olduğu,

Kat1limcilara,

$\checkmark$ Problemleri hiyerarşik şekilde organize etme firsatını verdiği,

$\checkmark$ Problemlere yorum yapma becerilerini geliştirdiği,

$\checkmark$ Problemleri çözmek için sorumluluk alma bilincini kazandırdığı,

$\checkmark$ Kendilerine olan güven duygusunu geliştirdiği,

$\checkmark$ Problem çözümlerinde geleneksel yöntem yerine öğrenci merkezli eğitimi nasıl yapacaklarını öğrendikleri,

$\checkmark$ Kalıcı öğrenme için derslerin öğrenci merkezli işlenmesi gerektiğini kavradıkları,

$\checkmark$ Problemlerin çözümlerinde görselleştirmenin önemli olduğunu gösterdiği,

$\checkmark$ Öğrenci katlımı için problem çözümlerini eğlenceli hale getirilmesi gerektiğini kavratmıştır.

Sonuç olarak, Analitik Kimya II dersindeki nicel analiz problemlerinin öğretimini kolaylaştırmak için akış şemalarının kullanılmasının iyi bir uygulama olduğu söylenebilir. Bu sonuçlar ışığında aşağıdaki öneriler verilebilir.

$\checkmark$ Problemlere çözüm üreten öğretmenlerin yetiştirilmesi için öncelikle onların lisans derslerinde problem çözme strateji, yöntem ve tekniklerin kullanılmasına önem verilmesi,

$\checkmark$ Araştırmadaki problemler ve akış şemaları kullanılarak Analitik Kimya II dersiyle ilişkili farklı alanlardaki katılımcılarla nitel veya nicel çalışmalar yapılması ve sonuçlarının karşılaştırılması,

Araştırmadaki problem ve akış şemaları kullanılarak öğrencilerin akademik başarısına, Analitik Kimya II dersine ve kimyaya karşı tutumlarına etkisi vb. araştırmalar yapılması önerilmektedir. 


\section{Kaynakça}

Altun, A. ve Emir, S. (2008). Sosyal bilgiler dersinde problem çözme yönteminin erişi, kalıcılığa ve tutuma etkisi. Hasan Ali Yücel Eğitim Fakültesi Dergisi, 2(10), 79-100.

Altun, M. ve Arslan, Ç. (2006). İlköğretim öğrencilerinin problem çözme stratejilerini öğrenmeleri üzerine bir çalışma. Uludağ Üniversitesi, Eğitim Fakültesi Dergisi 19 (1), 1-21.

Aksoy, B. (2003). Problem çözme yönteminin çevre eğitiminde uygulanması. Pamukkale Üniversitesi Eğitim Fakültesi Dergisi, 2 (14), 83-98.

Ayas, A. (1997). Kimya öğretimi. YÖK/Dünya Bankası Milli Eğitimi Geliştirme Projesi Hizmet Öncesi Öğretmen Eğitimi, Ankara.

Aydoğdu, A. (2000). Kimya öğretiminde zenginleştirilmiş öğretim ve geleneksel problem çözme etkinliklerinin kimya dersi başarısı açısından karşılaştırılması. Hacettepe Üniversitesi Eğitim Fakültesi Dergisi, 19, 29-31.

Bamidele, E. F., \& Oloyede, E. O. (2013). Comparative effectiveness of hierarchical, flowcharts and spider concept mapping strategies on students' performance in chemistry. World Journal of Education 3(1), 66-76.

Case, J. M., \& Fraser, D. M. (1999). An investigation into chemical engineering students understanding of the mole and the use of concrete activities to promote conceptual change. International Journal of Science Education. 21(2), 1237-1249.

Cheng, S.C., She, H.C. \& Huang, L.Y. (2018). The impact of problem- solving instruction on middle school student's physical science learning: interplays of knowledge reasoning and problem solving. Eurasia Journal of Mathematics, Science and Technology Education, 14(3), 731-743.

Copper, G., \& Swaller, J. (1987). Effect of schema acquisition and rule automation on mathematical problem-solving transfer. Journal of Educational Psychology, 79(4), 347-362.

Creswell, J. W. (2016). Research design qualitative, quantitative, and mixed methods approach, (Çev. Selçuk Beşir Demir. Araştırma deseni nitel ve karma yöntem yaklaşımları). Ankara: Eğiten Kitap, 2. Bask1.

Çalışkan, S., Sezgin-Selçuk G. ve Erol, M. (2006). Fizik öğretmen adaylarının problemi çözme davranışlarının değerlendirilmesi. Hacettepe Üniversitesi Eğitim Fakültesi Dergisi, 30,73-81.

Çalışkan, S., Sezgin-Selçuk G. ve Erol, M. (2010). The effects of the problem-solving strategies instruction on the students' physics problem solving performances and strategy usage. Procedia Social and Behavioural Sciences, 2, 2239-2243.

Danjuma, I. M. (2012). Analysis of pre-service teachers problem-solving characterises in solving chemistry problems. Education Research Journal 2(6), 208-222.

DeCaprio, S. A. (1981). Flowcharting: A method of problem solving. Teachers institute. Yale National Initiative. [Çevrim-içi: https://yale. edu/ curriculum/81.06.03.x.ht. 505]: erişim tarihi: 05.062019.

Doğanay, A. (2014). Öğretim ilke ve yöntemleri. Ankara, Pegem Akademi.

Ekiz, D. (2003). Eğitimde araştırma yöntem ve metotlarına giriş. Ankara, Anı Yayıncılık

Erden, M. (1986). İlkokulların birinci devresine devam eden öğrencilerin dört işleme dayalı problemleri çözerken gösterdikleri davranışları. Hacettepe Eğitim Fakültesi Dergisi, 1, 105-113.

Erdem, E. (2008). Genel kimya dersinde öğrencilerin kavram haritaları ve problem çözme inancının incelenmesi. Hacettepe Üniversitesi Ĕ̈itim Fakültesi Dergisi, 35, 111-122.

Eryılmaz-Toksoy, S. ve Akdeniz A.R. (2017). Öğrencilerin problemleri çözüm süreçlerinin ipucu destekli problem çözme aracı ile belirlenmesi. Hacettepe Üniversitesi Eğitim Fakültesi Dergisi, 32(1): 185208.

Gabel, D. L., Sherwood, R. D., \& Enoch, L. (1984). Problem-solving skills of high school chemistry students. Journal Research in Science Teaching, 21(2), 221-233.

Gelbal, S. (1991). Problem çözme. Hacettepe Üniversitesi Eğitim Fakültesi Dergisi, 6,167-173.

Gentles, S. J., Charles, C., Ploeg, J., \& Mckibben, K. A. (2015). Sampling in qualitative research: insights from an overview of methods literature. The Qualitative Report, 20(11), 1772-1789. 
Güneş, F. (2014). Öğretim ilke ve yöntemleri. Pegem Akademi, Ankara

Hafsah, T., Rosnani, H., Zurida, I., Kamanuzaman, J., \& Khoo, Y. Y. (2014). The influence of students' concept of mole, problem representation ability and mathematical ability on stoichiometry problem solving. The WEI International Academic Conference Proceedings, (122-136). Indonesia.

Harsh, S. (2011). Purposeful sampling in qualitative research synthesis. Qualitative Research Journal, 11(2), 63-75.

Hicks, R. W., \& Bevsek, H. M. (2012). Utilizing problem-based learning in qualitative analysis lab experiments. Journal Chemical Education. 89(2), 254-257.

Ilgın, H. ve Arslan, D. (2012). Türkçe dersinde metinlerle problem çözme öğretiminin öğrencilerin problem çözme becerilerine etkisi. Ahi Evran Üniversitesi Kırşehir Eğitim Fakültesi Dergisi, 13 (2), 157-176.

Işıkdoğan, N. ve Kargın, T. (2010). Hikâye haritası tekniğinin zihin engelli öğrencilerin okuduğunu anlama becerilerini kazanmalarındaki etkililiği. Kuram ve Uygulamada Eğitim Bilimleri, 10 (3), 1489-1531.

Johnson, B., \& Christensen, L. (2014). Educational research. (Çev. Selçuk Beşir Demir, Eğitim araştırmaları nitel ve nicel karma yaklaşımları). Ankara: Eğiten Kitap, 4. Baskı.

Lorenzo, M. (2005). The development, implementation, and evaluation of problem-solving heuristic. Journal of Science and Mathematics Education, 3, 33-58.

Karabulut, A., Yıkmış, A. Özak, H. ve Karabulut, H. (2015). Şemaya dayalı problem çözme stratejisinin zihinsel yetersizliği olan öğrencilerin problem çözme performanslarına etkisi. Abant İzzet Baysal Üniversitesi Ĕ̈itim Fakültesi Dergisi, 15 (Özel Sayı), 243-258.

Karaer, H. (2006). Fen bilgisi öğretmen adaylarının ilköğretim II. kademedeki fen bilgisi öğretimi hakkındaki görüşleri (Amasya örneği). Erzincan Eğitim Fakültesi Dergisi 8(2), 97-111.

Khan, S. N. (2014). Qualitative research method-phenomenology. Asian Social Science, 10(21), 298-310.

Kaya, Z. (2006). Öğretim teknolojileri ve materyal geliştirme. Ankara, Pegem, A Yayıncılık.

MEB, Millî Eğitim Bakanlığı (2018). Ortä̈ğretim kimya dersi öğretim programı. Ankara

Nakiboğlu, C. ve Kalın, Ş. (2009). Ortaöğretim öğrencilerinin kimyada problem çözme basamaklarının kullanımı ile ilgili düşünceleri. Kastamonu Eğitim Dergisi, 17(2), 715-725.

Nakiboğlu, C., Şen A.Z. Akgün, İ. ve Fidan, M. (2016). Genel kimya laboratuvarında akış diyagramı kullanımına yönelik öğretmen adaylarının görüşlerinin incelenmesi. Türkiye Kimya Derneğ $i$ Dergisi, Kısım C: Kimya Eğitimi, 1(1), 63-86.

Novak, J. D., \& Canas, A. L. (2006). The theory underlying concept maps and how to construct and use them. Technical report IHMC Cmap. Tools 2006-1. Florida institute for human and machine cognition, Pensacola

Novak, J. D., \& Canas, A. L. (2007). The theoretical origins of concept maps how to construct them and uses in education. Reflecting Education, 3(1), 29-42.

Okanlawon, A. E. (2010). Teaching reaction stoichiometry: Exploring and acknowledging Nigerian chemistry teachers 'pedagogical content knowledge. Cypriot Journal of Educational Sciences. 5, 107-129.

Önen, F., Saka, M., Erdem, A. ve Gürdal, A. (2008). Hizmet içi eğitime katılan fen bilgisi öğretmenlerinin öğretim tekniklerine ilişkin bilgilerindeki değişimin tespiti: Tekirdağ örneği. Ahi Evran Üniversitesi Eğitim Fakültesi Dergisi, 9(1), 45-57.

Padilla-Diaz, M. (2015). Phenomenology in educational qualitative research: Philosophy as science or philosophical science. International Journal of Education Excellence, 1(2), 101-110.

Patton, M. Q. (2015). Qualitative research \& evaluation methods: Integration, theory and practice Thousand oaks, CA: Sage (4th ed).

Sezgin-Selçuk, G. Çalışkan, S. ve Erol M. (2006). Problem çözme stratejilerin kullanımı ve fizik başarısı. Çăgdaş Ĕ̈itim Dergisi, 334, 15-23. 
Sezgin-Selçuk, G. Çalışkan, S. ve Erol M. (2007). The effects of gender and grade levels on Turkish physics teacher candidates 'problem solving strategies. Journal of Turkish Science Education 4 (1), 92-100.

Skoog, D.A. West, D. \& Holler, J. (1996). Analitik kimya temelleri (Çev. E Kılıç, F. Köseoğlu) Ankara: Bilim Yayıncılık.

Soylu, Y. ve Soylu, C. (2006). Matematik derslerinde başarıya giden yolda problem çözmenin rolü. İnönü Üniversitesi Eğitim Fakültesi Dergisi, 7(11), 97-111.

Tekşan, K. (2013). Ömer Seyfettin'in üç hikâyesinde problem çözme yöntemi ve bu hikâyelerin Türkçe öğretiminde kullanılması. Mehmet Akif Ersoy Üniversitesi Eğitim Fakültesi Dergisi, 25, 310-341.

Temel, S., ve Morgil, İ. (2013). Kimya laboratuvarında problem çözme. Pamukkale Üniversitesi Eğitim Fakültesi Dergisi, 33, 39-52.

Türker-Biber, B. ve Aylar, E. (2017). İlköğretim matematik öğretmen adaylarının problem çözmeye dair pedagojik alan bilgilerinin sınıf içi gözlem ve görüşme yoluyla belirlenmesi. Kastamonu Eğitim Dergisi, 25(4), 1483-1498.

Ünsal, Y. (2010). Problem çözmedeki anlam karmaşası. Eğitişsim Dergisi, 28: 15-16.

Ünsal, Y. ve Ergin, İ. (2011). Fen eğitiminde problem çözme sürecinde kullanılan problem çözme stratejileri ve örnek bir uygulama. Savunma Bilimleri Dergisi, 10(1), 72-91.

Ünsal, Y. ve Moğol, S. (2008). Fen eğitiminde problem çözme ile ilgili açıklamalı kaynakça. Dicle Üniversitesi, Ziya Gökalp Eğitim Fakültesi Dergisi, 10, 70-81.

Van Domelen, D. (2006). Problem-solving strategies: mapping and prescriptive methods. Department of Physics. The Ohio State University, Columbus, Ohio, 43210. [Çevrim-içi: https://eyrie. org/ dvandom/Edu/thesis.html ]: erişim tarihi: 05.062019

Waddling, R. E. L. (1983). Titration calculations a problem-solving approach. Journal of Chemical Education, 60(3), 30-32.

Wilder, S. (2014). Impact of problem-based learning on academic achievement in high school: A systematic review. Educational Review, 67(4), 1-22.

Yazgan, Y. (2007). Dördüncü ve beşinci sınıf öğrencilerinin rutin olmayan problem çözme stratejileriyle ilgili gözlemler. Illköğretim Online, 6(2), 249-263.

Yıldırım, A. ve Şimşek, H. (2006). Sosyal bilimlerde nitel araştırma yöntemleri. Ankara: Seçkin Yayınc1lik (6. Baski).

Yıldızlar, M. (2013). Öğretim ilke ve yöntemleri. Ankara: Pegem Akademi.

Yüksel, P. ve Yıldırım, S. (2015). Theoretical frameworks, methods, and procedures for conducting phenomenological studies in educational settings. Turkish Online Journal of Qualitative Inquiry, 6 (1), $1-10$ 


\section{Extended Abstract}

\section{Introduction}

The problem is a situation that makes people uneasy, has more than one solution, and their origins go back to human existence. When the condition of an actual situation and the conditions of a desired condition are different from each other, the problem emerges. People who face problems in their daily lives seek out various solutions to get rid of their problems. Although there are not all of these ways, they find solutions how to get rid of them and when they cannot find solutions, they search for new ways to get rid of it to get refaced.

There are many problems that need to be solved in the field of education as it is in every field. In contemporary education understanding which forms the basis of today's teaching programs; problem solving is regarded as learning skill. In this understanding, students should be able to find out the solution paths of the problem themselves when they face any problem and the teachers should show them the paths to reach the solution by guiding them rather than giving the problem solution directly to the students. The problem is that the first discipline that comes to mind is the basic sciences which are intertwined with mathematics or mathematics, but other disciplines also have problems, so all disciplines are used in the problem-solving method and they are included in the aims of the school programs. The problem-solving method is to help the students understand the problem, collect necessary data, realize what they want or what they don't want, create necessary plan, check whether the plan they created will take it to the end, and so on.

In the problem-solving process, teachers need to take advantage of student- centered contemporary methods, techniques and strategies that will attract the attention of student and focus on probing, instead of solving the problems with traditional methods. Otherwise, students will not be able to solve the problem, or the solution will be delayed. The type and complexity of problem is crucial in order to achieve the desired result in problem solving. Sometimes problems may require students to use scientific methods as well as logic when reaching the end result. Students who face with such a situation need to research, questions, decide, critically and reflectively, etc. so that they can cope with the problem. Therefore; it should be taught to students. For this it is necessary to take advantage of techniques that facilitate the solution of the problems and make learning fun, one of which is flowcharts.

This study is conducted to demonstrate usability of flowcharts and to determine opinions of teacher candidates on the use of flowcharts in teaching of quantitative analysis problems in Analytical chemistry II course.

\section{Method}

In this study, the phenomenology (case-science) pattern was used. The study group consisted of 13 students enrolled in Analytical chemistry II course, which was taught as a compulsory course in the second year of chemistry teaching program of the education faculty of a state university in Turkey. The data were collected from the flowcharts drawn at lesson, from the qualitative observations identified during the drawing of the flowcharts of the problems in the course, from the feedback form and the answers to the questions in the semi structured interviews with 
volunteer participants. In the analysis of the data, frequency and percent ration are given by creating categories and codes in a way that readers can understand using content analysis.

\section{Findings}

According to the findings, the useful of flowcharts in teaching of the problems is a quite good, makes it easier to solve problems, reduces the probability of students making mistakes gives the ability to reach the right result and makes problem solving fun and so on positive opinions were determined. In addition, teacher candidates state that when they are teachers, they will teach their students at their lessons using contemporary teaching methods and techniques instead of traditional methods.

\section{Discussion, Conclusion and Suggestions}

As a result, it can be said that it is appropriate to use flow charts to facilitate the teaching of quantitative analysis problem, to provide students with problem solving skills, and to ensure that their behavior against problem solving develops positively. It is recommended that teacher candidates should be educated with such methods and techniques in their undergraduate training for future course of student-centered education. 